\title{
Rhizosphere Microbiomes of European Seagrasses Are Selected by the Plant, But Are Not Species Specific
}

\author{
Catarina Cúcio', Aschwin H. Engelen ${ }^{2}$, Rodrigo Costa ${ }^{3 \dagger}$ and Gerard Muyzer ${ }^{1 *}$ \\ 'Microbial Systems Ecology, Department of Aquatic Microbiology, Institute for Biodiversity and Ecosystem Dynamics, \\ University of Amsterdam, Amsterdam, Netherlands, ${ }^{2}$ Marine Ecology and Evolution Research Group, Centro de Ciencias do \\ Mar, Universidade do Algarve, Faro, Portugal, ${ }^{3}$ Microbial Ecology and Evolution Research Group, Centro de Ciencias do \\ Mar, Universidade do Algarve, Faro, Portugal
}

OPEN ACCESS

Edited by:

Dennis A. Bazylinski, University of Nevada at Las Vegas,

USA

Reviewed by:

Byron C. Crump,

Oregon State University, USA

Zhanfei Liu,

The University of Texas at Austin, USA

${ }^{*}$ Correspondence: Gerard Muyzer

g.muijzer@uva.nl

tPresent address: Rodrigo Costa, Institute for Bioengineering and

Biosciences, Department of Bioengineering, Instituto Superior Técnico, Universidade de Lisboa, Lisbon, Portugal

Specialty section: This article was submitted to Aquatic Microbiology, a section of the journal

Frontiers in Microbiology

Received: 02 December 2015 Accepted: 18 March 2016 Published: 31 March 2016

Citation:

Cúcio C, Engelen AH, Costa $R$ and Muyzer G (2016) Rhizosphere Microbiomes of European Seagrasses Are Selected by the Plant, But Are

Not Species Specific.

Front. Microbiol. 7:440.

doi: 10.3389/fmicb.2016.00440
Seagrasses are marine flowering plants growing in soft-body sediments of intertidal and shallow sub-tidal zones. They play an important role in coastal ecosystems by stabilizing sediments, providing food and shelter for animals, and recycling nutrients. Like other plants, seagrasses live intimately with both beneficial and unfavorable microorganisms. Although much is known about the microbiomes of terrestrial plants, little is known about the microbiomes of seagrasses. Here we present the results of a detailed study on the rhizosphere microbiome of seagrass species across the North-eastern Atlantic Ocean: Zostera marina, Zostera noltii, and Cymodocea nodosa. High-resolution amplicon sequencing of $16 \mathrm{~S}$ rRNA genes showed that the rhizobiomes were significantly different from the bacterial communities of surrounding bulk sediment and seawater. Although we found no significant differences between the rhizobiomes of different seagrass species within the same region, those of seagrasses in different geographical locations differed strongly. These results strongly suggest that the seagrass rhizobiomes are shaped by plant metabolism, but not coevolved with their host. The core rhizobiome of seagrasses includes mostly bacteria involved in the sulfur cycle, thereby highlighting the importance of sulfur-related processes in seagrass ecosystems.

Keywords: 16S rRNA, amplicon sequencing, marine bacteria, rhizosphere, seagrass microbiome, sulfur bacteria, sulfur cycle, plant-microbe interactions

\section{INTRODUCTION}

In recent years many studies have been conducted on the composition, activity, and interaction of bacterial communities and terrestrial plants (e.g., Egamberdieva et al., 2008; Bulgarelli et al., 2012; Philippot et al., 2013; Chaparro et al., 2014; Ofek-Lalzar et al., 2014). Most of this research has been focused on the rhizosphere, a thin zone of soil under direct influence of root exudates, also known as 'rhizodeposits' (Martens, 1990). The type and quantity of rhizodeposits shape the composition of bacteria present in the rhizosphere, the 'rhizobacteria' (Kloepper and Schroth, 1979; Lugtenberg and Kamilova, 2009). These rhizobacteria are a diverse mixture of microorganisms that can actively interact with the plant in different ways and include both pathogenic and pathogen-suppressing bacteria, as well as bacteria that can enhance the plant's fitness for 
example by releasing growth-promoting factors (Mendes et al., 2011, 2013; Berendsen et al., 2012; Bulgarelli et al., 2013) or by fixing nitrogen (Spaink, 2000; Mehnaz et al., 2007; Miller et al., 2007).

Although the rhizosphere microbiome of terrestrial plants is well studied, little is known about the bacteria living in close association with marine plants, such as seagrasses. Seagrasses are a paraphyletic group of angiosperms, which recolonized the marine environment. Their primary and secondary metabolism is similar to that of terrestrial plants due to their common evolutionary origin (Agostini et al., 1998; Heglmeier and Zidorn, 2010). Four families within the order Alismatales, the Cymodoceaceae, Hydrocharitaceae, Posidoniaceae, and Zosteraceae, exclusively contain marine plant species (den Hartog and Kuo, 2006), which are distributed mostly in soft-bottom sediments of intertidal and shallow sub-tidal areas from tropical to cold-temperate coastal zones (Fonseca et al., 2000; Papenbrock, 2012). Seagrasses are important ecosystem engineers that provide feeding grounds and habitats to a large variety of marine organisms. Their canopies and dense meadows are responsible for trapping substantial amounts of sediment particles and organic matter (Gacia et al., 1999) enhancing water clarity, and account for roughly $10 \%$ of the yearly global carbon sequestration in marine sediments (Duarte et al., 2005b; Kennedy et al., 2010; Fourqurean et al., 2012).

Sediments inhabited by seagrasses are typically anoxic and highly reduced due to the presence of sulfide, which is a strong phytotoxin (Koch and Erskine, 2001) responsible for die-off events of seagrasses (Borum et al., 2005; Krause-Jensen et al., 2011). Sulfide is a product from the activity of sulfatereducing bacteria that use sulfate as a terminal electron acceptor for the mineralization of organic matter (Capone and Kiene, 1988). The availability of diverse terminal electron acceptors and the exudates released by seagrass roots stimulate bacterial growth and promote a series of microbial-mediated redox processes in the rhizosphere, resulting in an extensive range of microenvironments readily available for the establishment of complex microbial communities (Isaksen and Finster, 1996; Holmer and Nielsen, 1997; Blaabjerg and Finster, 1998; Hansen et al., 2000; Devereux, 2005; Duarte et al., 2005a).

Some studies have investigated the belowground microbial diversity associated with seagrass meadows including rhizosphere, rhizoplane, and endosphere (e.g., Cifuentes et al., 2000, 2003; James et al., 2006; Jensen et al., 2007; Crump and Koch, 2008; Mejia et al., 2016), and these belowground niches have been described to be dominated mostly by members of the classes Alpha-, Gamma-, Delta-, Epsilonproteobacteria, and/or Bacteroidetes (Cifuentes et al., 2000; Jensen et al., 2007; Mejia et al., 2016). Nonetheless, the majority of these studies have been performed on a small number of seagrass species, and it is not always clear which structure was sampled.

Here, we used high-resolution amplicon sequencing of $16 \mathrm{~S}$ rRNA genes to characterize, for the first time, the rhizosphere microbiome (hereinafter referred to as rhizobiome) of seagrasses from the North-eastern Atlantic Ocean: the common eelgrass Zostera marina, the dwarf eelgrass Zostera noltii, and the little Neptune grass Cymodocea nodosa. We studied the variation between rhizobiomes of $Z$. marina and Z. noltii from the South of Portugal and the North of France, and characterized the core rhizobiome of North-eastern Atlantic seagrasses. In addition, we discussed the possible niche occupation of sulfur bacteria in these rhizobiomes, due to the importance of the sulfur cycle on the fitness and survival of seagrasses.

\section{MATERIALS AND METHODS}

\section{Description of Sampling Sites}

Rhizospheres from Zostera marina $(\mathrm{Zm} / \mathrm{ZmPt}), \quad Z$. noltii $(\mathrm{Zn} / \mathrm{ZnPt})$ and Cymodocea nodosa $(\mathrm{Cn} / \mathrm{CnPt})$, as well as bulk sediment $(\mathrm{Sed} / \mathrm{SedPt})$ and seawater $(\mathrm{SW} / \mathrm{SwPt})$ were sampled from the intertidal regions of Culatra Island (Faro, Portugal, $36^{\circ} 59^{\prime} 56.0^{\prime \prime} \mathrm{N} 7^{\circ} 49^{\prime} 31.7^{\prime \prime} \mathrm{W}$ ) in July 2013. The three seagrass species collected in Portugal were located in adjacent meadows; therefore bulk sediment and seawater samples were obtained from one single site on their surroundings. Culatra Island is one of five islands in the Ria Formosa lagoon, a meso-tidal system with a surface area of $84 \mathrm{~km}^{2}$ (Cabaço and Santos, 2010). This island is one of the few locations in the Ria Formosa where these three seagrasses coexist. They inhabit mostly sandy sediments (Asmus et al., 2000), although there is a high variability in sediment characteristics at a very small scale (Falcão and Vale, 1990). The salinity is typically 36 PSU although it can sporadically decrease to $27 \mathrm{PSU}$, and seawater temperature ranges between $12^{\circ} \mathrm{C}$ in winter and $27^{\circ} \mathrm{C}$ in summer (Newton and Mudge, 2003).

In order to compare rhizobiomes across regions, rhizospheres of $Z$. marina were collected from Pointe de Cléguer $(\mathrm{Zm} / \mathrm{ZmFr}$, Roscoff, France, $48^{\circ} 43^{\prime} 37.1^{\prime \prime} \mathrm{N} 3^{\circ} 58^{\prime} 35.9^{\prime \prime} \mathrm{W}$ ) and Z. noltii from Penar Vil (Zn/ZnFr, Roscoff, France, $48^{\circ} 41^{\prime} 27.4^{\prime \prime} \mathrm{N}$ $3^{\circ} 57^{\prime} 24.9^{\prime \prime} \mathrm{W}$ ), in September 2013. Two sets of bulk sediments were collected, one in the surroundings of $Z$. marina (SedM, SedMFr) and another one in the surroundings of the $Z$. noltii meadow (SedN, SedNFr). Cymodocea nodosa was not sampled from Roscoff, due to its Mediterranean-Atlantic geographical distribution. Roscoff, which is located in northern Brittany, France, has a mega-tidal system with a patchy coverage of $Z$. noltii and $Z$. marina beds growing in sandy sediments (median grain size: $252 \pm 10$ and $302 \pm 11 \mu \mathrm{m}$, respectively; Ouisse et al., 2010) with low organic matter content $(1.12 \pm 0.19$ and $1.86 \pm 0.51 \%$, respectively; Ouisse et al., 2012). Salinity varies between 21 and $35 \mathrm{PSU}$, and seawater temperature between 7 and $23^{\circ} \mathrm{C}$ (Bachelet et al., 1992; Li et al., 2009).

\section{Sampling Strategy}

Five $15 \mathrm{~cm}$ diameter cores of each seagrass species were randomly collected during low tide. In addition, bulk sediments were collected from a depth of $1-11 \mathrm{~cm}$ representing the root zones of the seagrasses, using $50 \mathrm{~mL}$ syringes $(n=5)$, and seawater ( $1 \mathrm{~L}, n=5)$. To obtain the rhizosphere from the seagrasses we adapted a method that is commonly used for the retrieval of rhizospheres from terrestrial plants (e.g., Shieh and Yang, 1997; Costa et al., 2006; Lundberg et al., 2012). Briefly, each seagrass core was slowly emptied in a tray, maintaining the structure of the sectioned sediment intact. 
Sandy sediments, such as those present in the sampling areas (Ouisse et al., 2012), are strongly trapped within the root structure of the seagrasses, in particular by $Z$. noltii. Therefore, the complex network of roots was carefully separated by gently shaking the tray sideways, and 4-6 shoots from each core were selected for rhizosphere recovery. Thereafter, roots from the selected seagrasses were manually shaken in order to remove loose sediment (which was excluded from the collection), and the sediment that remained attached to the roots (rhizosphere) was collected for further analysis by washing the roots with $0.2 \mu \mathrm{m}$-filtered seawater. Additionally, $5 \mathrm{~cm}$ diameter cores were collected in triplicate from each seagrass and bulk sediment, for sediment characterization. Samples were transported to the laboratory in a cool-box and immediately processed on arrival.

\section{DNA Extraction and 16S Amplicon Sequencing}

For each of the five seawater replicates, $600 \mathrm{~mL}$ of seawater was filtered through a $0.2 \mu \mathrm{m}$-pore size nitrocellulose filter to collect microbial biomass. Rhizosphere and bulk sediment samples were checked for meiofauna and plant detritus, which were removed if present. Thereafter they were processed in a Stomacher 80 Laboratory Blender (Seward Medical) for 3 cycles of $1 \mathrm{~min}$ at normal speed, in order to release microbial cells from the mineral particles (Buesing and Gessner, 2002). The supernatant was centrifuged for $30 \mathrm{~min}$ at high speed $(10,000 \mathrm{~g}$ ) (Costa et al., 2006), after which the pellet containing the microbial biomass was processed immediately. The DNA from filters and microbial pellets from rhizosphere and bulk sediments was extracted using the PowerSoil DNA Isolation Kit (MO BIO Laboratories, Inc., Carlsbad, CA, USA), following the manufacturer's instructions. The isolated DNA was quantified using a dsDNA HS Assay Kit on a Qubit 2.0 Fluorometer (Life Technologies, Grand Island, NY, USA).

Sequencing was performed on an Illumina MiSeq system by the company Research and Testing Laboratory (Lubbock, TX, USA). The $16 \mathrm{~S}$ rRNA gene libraries were prepared according to a modified protocol from Kozich et al. (2013). Briefly, amplification was performed using a forward and reverse fusion primer. The primer pair S-D-Bact-0341-b-S-17, 5'-CCTACGGGNGGCWGCAG-3' and S-D-Bact-0785-a-A-21, 5'-GACTACHVGGGTATCTAATCC-3' (Herlemann et al., 2011) was used to generate $464 \mathrm{bp}$ paired-end reads, covering the V3-V4 16S rRNA region. The forward primer S-D-Bact-0341-b -S-17 was complemented with an Illumina i5 adapter $\left(5^{\prime}\right.$ - AA TGATACGGCGACCACCGAGATCTACAC- $\left.3^{\prime}\right)$, and the reverse primer with an i7 adapter (5'-CAAGCAGAAGACGGCATAC GAGAT- $3^{\prime}$ ). Furthermore, an $8-10$ bp barcode and a primer pad sequence were added to each primer. The pad sequences were designed in order to guarantee a melting temperature between 63 and $66^{\circ} \mathrm{C}$ for each primer/pad combination. Amplifications were performed using the Qiagen HotStar Taq master mix (Qiagen Inc, Valencia, CA, USA), $1 \mu \mathrm{l}$ of each primer $(5 \mu \mathrm{M})$ and $1 \mu \mathrm{l}$ of template, in a total volume of $25 \mu \mathrm{l}$ per reaction. PCR amplification started with an initial denaturation step at $95^{\circ} \mathrm{C}$ for $5 \mathrm{~min}$, followed by 35 cycles at $94^{\circ} \mathrm{C}$ for $30 \mathrm{~s}, 54^{\circ} \mathrm{C}$ for $40 \mathrm{~s}$ and $72^{\circ} \mathrm{C}$ for $1 \mathrm{~min}$. The reaction was stopped after a final extension step at $72^{\circ} \mathrm{C}$ for $10 \mathrm{~min}$. Subsequently, the amplicons were visualized on an eGel, pooled and quantified before they were loaded on an Illumina MiSeq system (Illumina, Inc. San Diego, CA, USA). A total of 2,566,312 reads were generated from the 45 samples, with an average sequence length of $427 \mathrm{bp}$. After quality filtering, a total of $1,065,217$ sequences remained, with an overall average of $23,671 \pm 7,561$ sequences per sample and $6,950 \pm 1,856$ unique sequences per sample.

\section{Post-sequencing Analysis}

Post-sequencing analyses were performed on each biological replicate (Prosser, 2010). Sequencing data was analyzed using QIIME (version 1.7.0, Caporaso et al., 2010b). Briefly, raw sequences with merged paired-ends were demultiplexed and quality filtered. Primer detection was disabled in QIIME, because MiSeq sequencing does not sequence the primers. Subsequently, the sequences were clustered in operational taxonomic units (OTUs) using UCLUST (Edgar, 2010) with a sequence similarity threshold of $97 \%$. A representative set of OTUs was selected and aligned using the PyNAST algorithm (Caporaso et al., 2010a). All sequences that failed the alignment and singleton OTUs were not included in the analyses. Taxonomy assignment was performed with RDP classifier using the May 2013 release of Greengenes as a reference dataset (http://greengenes.lbl.gov/). An OTU table was built excluding sequences with no hit or matching chloroplast DNA. Core OTUs were defined as those present in $100 \%$ of the seagrass samples, including all 5 replicates of each species/location.

The sequencing method and data analysis applied in this work resulted in high quality reads; however we acknowledge the biases associated with amplicon-based sequencing methods, and the presence of multiple sequence copies. Nevertheless, the results here described were identical and comparable to those obtained through the analysis of $16 \mathrm{~S}$ rDNA reads obtained by Illumina shotgun sequencing of pooled replicates from four of the samples here analyzed. Moreover, the quality check and singleton removal abovementioned enabled us to provide a reproducible and reliable description (quantitatively and qualitatively) of the seagrass rhizobiome. Alpha diversity measures (Shannon Index of diversity and observed OTUs) were calculated based on rarefied OTUs, with 8055 sequences per sample, the maximum number of sequences common to all samples.

Differences between samples (beta diversity) were calculated in STAMP v2.0.8 (Parks et al., 2014), using the data generated by QIIME's taxonomy assignment and corresponding mapping file. STAMP calculated diversity differences between samples based on the analysis of variances (ANOVA) with a significant level of $P<0.05$, and significant differences between groups of samples were investigated using Scheffés post hoc test. BenjaminiHochberg's False Discovery Rate (FDR) was applied to correct for multiple comparisons.

Permutational Multivariate Analysis of Variance (PERMA NOVA) was applied to identify compositional differences between regions and seagrass species with a significance level of $P<0.01$, based on a Bray-Curtis distance matrix calculated in 
A

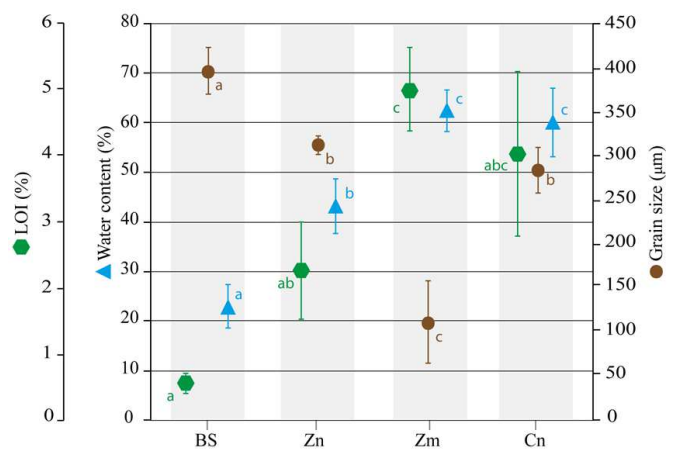

B

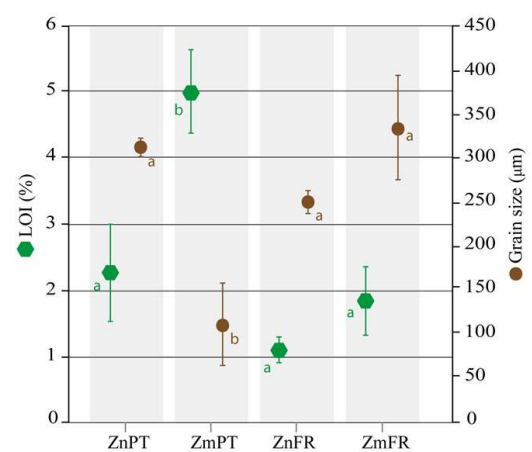

FIGURE 1 | Abiotic characterization of sediments from the study areas in Portugal and France. Mean percentages of water content, loss on ignition (LOI), as well as median grain size are shown for bulk sediments (BS) and sediments of Z. noltii (Zn), Z. marina (Zm), and C. nodosa (Cn) sampled in Portugal (A). Comparison of LOI and grain size Zostera spp. sediments between Portugal and France. The data of ZnFr and ZmFr were obtained from Ouisse et al. (2010, 2012) (B). Bars indicate standard deviations, and letters reveal presence/absence of significant relationships between samples on each analysis with a significance level of 0.05 , as determined by Tukey's HSD post hoc test.

PAST software version 2.17c (Hammer et al., 2001). Similarity Percentage method (SIMPER, Clarke, 1993) was used to assess which taxa were responsible for differences observed between two groups of samples (pairwise SIMPER) or between all the samples pooled (multi-group SIMPER), using a Bray-Curtis dissimilarity matrix, calculated, as abovementioned, in PAST software.

The amplicon sequences have been deposited as dataset SRP057630 in the Sequence Read Archive (SRA, EMBL).

\section{Abiotic Characterization of Sediments from Portugal}

Grain size determination was performed by standard sieve fractionation of the top $5 \mathrm{~cm}$ of small sediment cores, as described by Holme and McIntyre (1984). Due to the agglomeration of very fine particles $(<43 \mu \mathrm{m})$ and blockage of the sieve during dry sieving, wet sieving was manually performed on pre-weighed, oven-dried sediments $\left(105^{\circ} \mathrm{C}\right.$ overnight), through a $63 \mu \mathrm{m}$ mesh size (Krause-Jensen et al., 2011). Wet-sieved sediments were again dried at $105^{\circ} \mathrm{C}$ and sieved in a throwaction sieve shaker (10 min, amplitude $30 \mathrm{~mm}$; AS Basic, Retsch GmbH Haan), through 6 different mesh sieves (0.063, $0.125,0.250 .5,1$, and $2 \mathrm{~mm}$ ). Each size fraction was weighed, and the curve of cumulative percentages of each fraction was used to calculate median grain size. Sediment classification was subsequently performed according to Wentworth's grain size classes (Wentworth, 1922).

Water content was calculated after drying the top $1 \mathrm{~cm}$ of sediment at $105^{\circ} \mathrm{C}$ overnight, and loss on ignition (LOI) followed by overnight combustion at $375^{\circ} \mathrm{C}$ (Sutherland, 1998). The majority of studies determine LOI through combustion at 520 or $550^{\circ} \mathrm{C}$, however it has been reported that loss of structural water from metal oxides and clay minerals can take place at temperatures as low as $400^{\circ} \mathrm{C}$ (Dean, 1974; Sutherland, 1998). Due to a high percentage of small particles in some of the samples $(<63 \mu \mathrm{m})$, we considered that combustion at $375^{\circ} \mathrm{C}$ would provide more accurate results.
Differences between water content, LOI and grain size of sediments from Portugal, as well as grain size from France were analyzed using a one-way ANOVA, and differences between pairs of samples were assessed with Tukey's HSD post hoc test with a significance level of $P<0.05$. In order to investigate differences in organic content between Portugal and France, a two-sample $t$-test was performed on the online tool http://in-silico.net.

\section{RESULTS}

\section{Sediment Characteristics}

Standard sieve fractionation revealed that the grain size of sediments sampled in Portugal significantly differed between distinct sources of samples (ANOVA, $P=0.0002 \mathrm{e}-01$ ). Based on Wentworth's size classes, sediments of $Z$. noltii (mean $\pm \mathrm{SD}$, $311 \pm 11 \mu \mathrm{m})$, C. nodosa $(284 \pm 26 \mu \mathrm{m})$ and bulk sediments $(396 \pm 26 \mu \mathrm{m})$ were classified as medium sand, whereas sediment of $Z$. marina was classified as very fine sand (111 $\pm 47 \mu \mathrm{m})$. Nevertheless, significant sediment composition differences were detected among all samples except between $Z$. noltii and C. nodosa $(P=0.6704$, Figure 1A). Regarding grain size distribution of Zostera sp. sediments in Portugal and France, the only significant difference detected was between $Z$. marina sampled in Portugal, and all other samples $(P<0.001$, Figure 1B).

Water content was significantly lower in bulk sediments and $Z$. noltii than in $Z$. marina and $C$. nodosa $(P<0.01)$, and did not differ between the latter two species $(P=0.9000$, Figure 1A).

The organic content inferred from LOI at $375^{\circ} \mathrm{C}$ was significantly higher in sediments of $Z$. marina and $C$. nodosa than in bulk sediments $(P=0.0010$ and $P=0.0031$, respectively, Figure 1A), however, pairwise comparison of the latter with sediments from $Z$. noltii revealed no significant differences between them $(P=0.1148$, Figure 1A). Following the same trend observed in the comparison of grain size distribution 
between Portugal and France, only $Z$. marina sediments from the former location were significantly different from all other samples $(P=0.0032$, Figure 1B $)$.

\section{Microbial Community Composition of Rhizospheres and Surrounding Environment}

Comparative analysis of the amplicon sequences showed in both regions strong differentiation in bacterial communities between the seagrass rhizobiomes and those present in bulk sediments and seawater (Portugal: PERMANOVA, $P=0.0006$; Figures 2A,B; France: PERMANOVA, $P=0.0001$; Figures 2C,D). The rhizobiomes were dominated by members of the classes Gamma(Figure 3A), Delta- (especially in Portugal; Figure 3B), and Epsilonproteobacteria (especially in France; Figure $3 \mathrm{C}$ ), and Bacteroidia (Figure 3D), while the seawater was dominated by members of the Alpha- (Figure 3E), Gammaproteobacteria and Flavobacteriia (Figure 3F). Communities from the bulk sediments were predominantly composed of members from the Alpha-, Gamma-, and Deltaproteobacteria classes.

Rarefaction analysis showed that seawater accounted for the lowest diversity (Shannon index $=7.1$, and 1803 observed OTUs on rarefied samples). Furthermore, in general, the diversity of bulk sediments did not differ from the rhizosphere (Shannon index of 10.33 and 10.32, respectively; PERMANOVA, $P=0.8749$ ). On the other hand, although not statistically significant, the OTU richness was higher in bulk sediments than in rhizospheres (3522.5 and 3471.5 observed OTUs, respectively; PERMANOVA, $P=0.6944)$.

\section{Rhizobiomes of Different Seagrasses Within and Across Regions}

Principal component analysis showed that the rhizobiomes of $Z$. marina and $Z$. noltii within regions were highly similar, but strongly different from the rhizobiomes of the same species between regions (Figure 4).

The rhizosphere community composition of $Z$. marina, $Z$. noltii, and C. nodosa from Portugal was highly similar both at the phylum and class level (PERMANOVA, $P=0.1067$ and $P=0.0706$, respectively). Proteobacteria was the most abundant phylum among all three species, representing 65-68\% of all OTUs. Other dominant phyla were Bacteroidetes, which accounted for 10-12\%, Chloroflexi (4-5\%), Planctomycetes (2$3.5 \%)$, Actinobacteria (2.5-3\%), and Acidobacteria (2.2-2.6\%). The most abundant classes detected were Gammaproteobacteria (32-38\%) and Deltaproteobacteria (23-26\%) from the phylum Proteobacteria, followed by Bacteroidia (Bacteroidetes, 6-7\%), Epsilonproteobacteria (Proteobacteria, 2.7-4.4\%), Anaerolineae (Chloroflexi, 4\%), Acidimicrobiia (Actinobacteria, 2-2.6\%), and Alphaproteobacteria (Proteobacteria, 1.5-2.7\%).

The rhizobiomes of $Z$. marina and $Z$. noltii from France did not differ at the phylum level (PERMANOVA, $P=0.0166$ ). Proteobacteria were dominant in the rhizobiomes of both seagrass species (46.6 and 41\%, respectively) followed by Bacteroidetes (27.4 and 22.8\%), Firmicutes (6.7 and 9\%) and Actinobacteria (5 and 6.9\%). At the class level, however, there were some differences in relative abundances (PERMANOVA, $P=0.0077$ ). SIMPER analysis revealed that the Epsilonproteobacteria was the main taxon responsible for the differences observed between these two seagrasses in France, contributing $21.9 \%$ to the observed variation, followed by Flavobacteriia (8.6\%), Gammaproteobacteria (7.5\%), Deltaproteobacteria (7.3\%), Alphaproteobacteria (7.3\%), and Clostridia (7.2\%). For a complete overview of the relative abundance of individual taxa at the phylum and class levels, see Supplementary Tables S1 and S2, respectively. Furthermore, the classes contributing the most for the differences observed between Portugal and France were dominated by families typically involved in the sulfur cycle (Supplementary Table S2).

\section{Core Seagrass Rhizobiome}

The bacterial communities of the different seagrass species were compared in order to reveal a core rhizobiome comprehending the OTUs present in all the rhizospheres (Figure 5, Supplementary Table S3). Only $0.2 \%$ of the OTUs and $15 \%$ of sequences present in all the samples were identified as core rhizobiome, and included members from the phyla Proteobacteria, Bacteroidetes, Actinobacteria, Acidobacteria, Firmicutes, WS3, Chloroflexi, Caldithrix, and Gemmatimonadetes (Supplementary Table S3). Sixty-four percent of the core taxa belonged to the Proteobacteria, with representatives of the classes Alpha-, Gamma-, Delta-, and Epsilonproteobacteria (Supplementary Table S3).

\section{DISCUSSION}

In this study, we evaluated differences between the microbial community structure of the rhizosphere of three seagrass species and their surrounding environment, as well as between two distant geographic locations. Rhizosphere, rhizoplane and endophytic compartments are different niches that host distinct microbial communities around, on and inside root surfaces, respectively. Here, we document the lack of significant differences between the rhizosphere microbiome of different seagrass species from one location. However it is noteworthy that further investigation into the composition of rhizoplane and endophytic compartments can possibly result in differences between seagrass species (Bulgarelli et al., 2012; Lundberg et al., 2012). The intimacy of the association between plant and microbe is expected to rise with increased proximity to the roots, due to direct contact with the plant and stronger exposure to its exudates (Bulgarelli et al., 2012; Lundberg et al., 2012).

\section{Rhizobiomes of Different Seagrasses Within and across Regions}

Microbial assemblages in the rhizosphere of terrestrial plants have been shown to be shaped, for instance, by plant species (Berg and Smalla, 2009) and host genotype (Lundberg et al., 2012), and to vary according to the developmental stage of the plant (Chaparro et al., 2014) and type of soil/sediment (e.g., Berg and Smalla, 2009; Lundberg et al., 2012; Tkacz et al., 2015). It has also been demonstrated that microbial activity is sensitive 
A

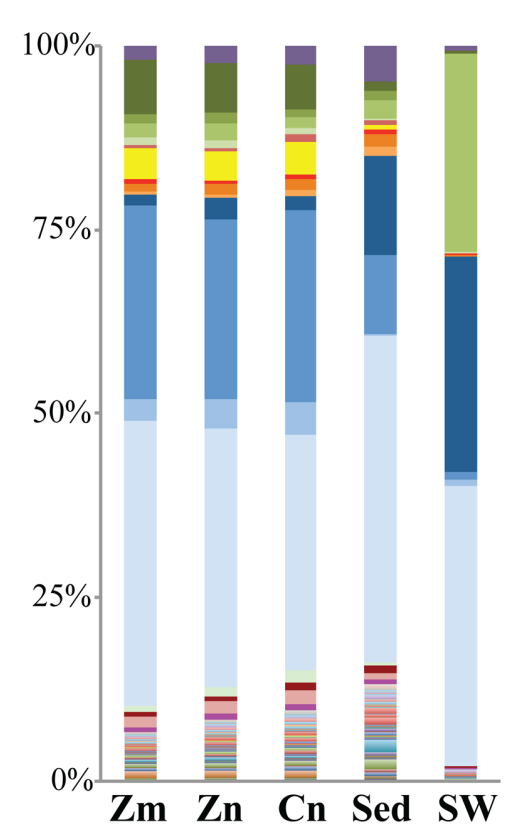

B

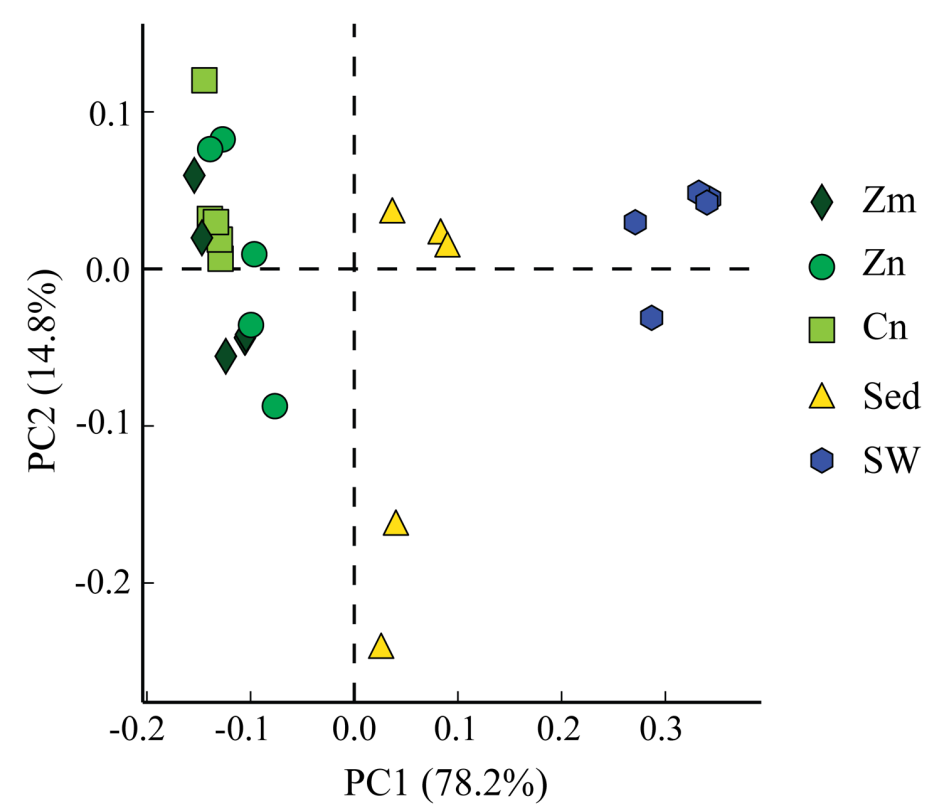

OS-K $\square$ Acidimicrobiia $\square$ Bacteroidia $\square$ Cytophagia $\square$ Flavobacteriia $\backsim$ Saprospirae

- Uncl Bacteroidetes Caldithrixae Anaerolineae Clostridia Planctomycetia

- Phycisphaerae $\backsim$ Alphaproteobacteria $\backsim$ Deltaproteobacteria Epsilonproteobacteria

- Gammaproteobacteria Spirochaetes $\quad$ Verrucomicrobiae $\backsim$ Verruco-5 PRR-12 Other

C

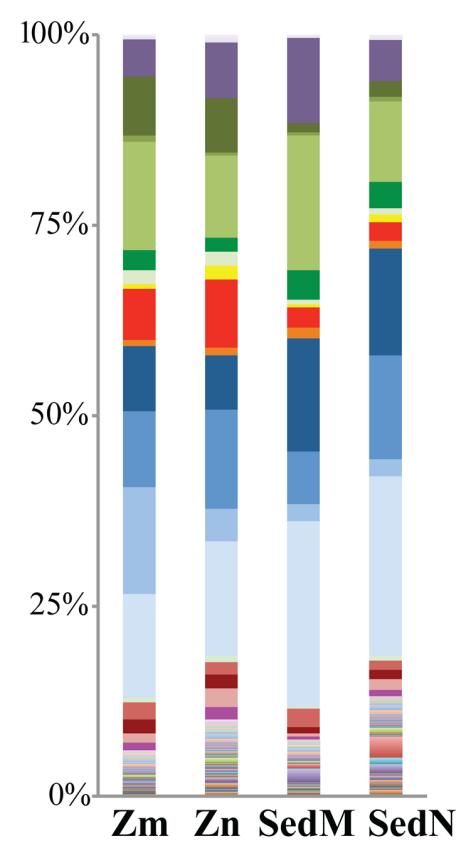

D

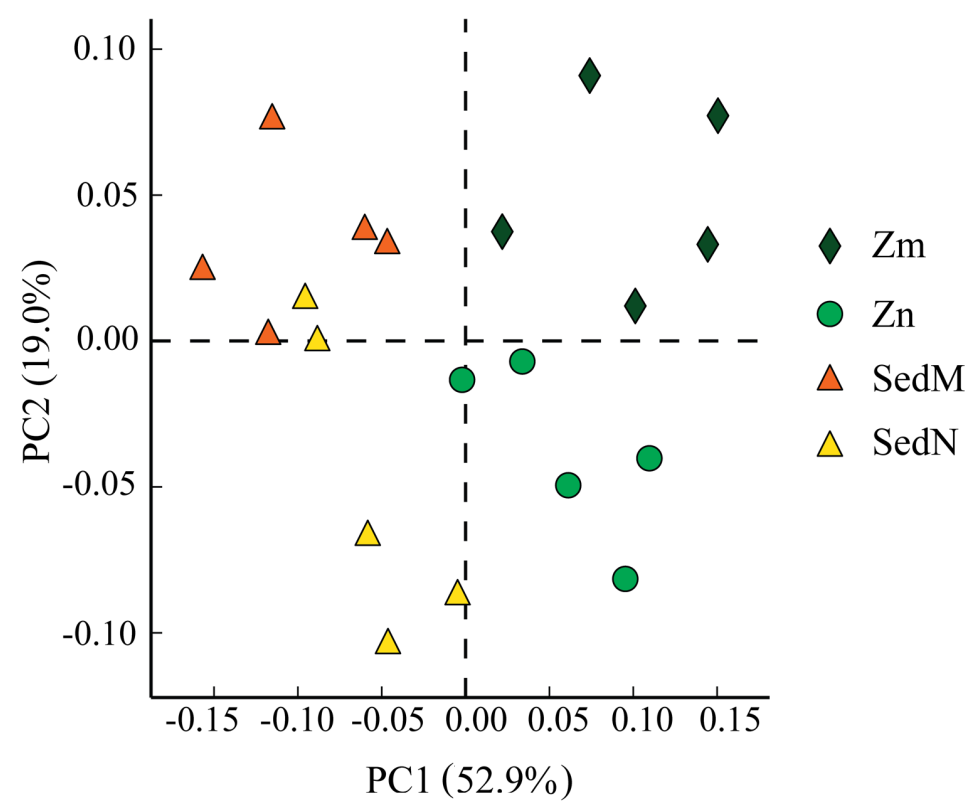

FIGURE 2 | Continued 


\section{FIGURE 2 | Continued}

Comparison of bacterial communities of the seagrass rhizosphere (Z. marina, Zm; Z. noltii, ZN; C. nodosa, CN) and the surrounding environment (bulk sediment, Sed; and seawater (SW) from Portugal and France. Bulk sediments from the surroundings of $Z$. marina and $Z$. noltii are distinguished (SedM and SedN, respectively). Shown are the bacterial community compositions (average of five independent samples) from (A) Portugal and (C) France, and principal component analysis (PCA) of the bacterial communities from (B) Portugal and (D) France. Both PCAs show a clear separation between the bacterial communities of the rhizosphere and those from the surrounding environment. Only classes represented by an average abundance above $0.5 \%$ are shown on the legend of the bar graphs $(\mathbf{A}, \mathbf{C})$, and the percentage of community variance explained by each axis is indicated in parentheses (B,D).

to seasonal changes in seagrass beds (Smith et al., 2004). The type of soil and its particular physico-chemical characteristics have been repeatedly named as determinant for the community structure in the rhizosphere of terrestrial plants, while at the same time plants also influence soil properties (Philippot et al., 2013). Recently, Tkacz et al. (2015) concluded that the rhizobiome is controlled by soil composition along with plant type. Even though there is a vast amount of information that attributes differences in rhizobiomes to the type of soil/sediment, to our knowledge there is no information regarding the identity of their particular properties. Because grain size, organic matter and water content directly affect sediment's microbial communities and plant morphology (Wicks et al., 2009), they were used in this study as indicators of different types of sediment. Our results highlight that the grain size of Z. marina sediments in Portugal was significantly smaller than that of sediments inhabited by the other two seagrasses (very fine sand vs. medium sand, respectively), which corresponded with the higher organic matter and water contents observed in the sediments of this species. Fine sediments tend to have a higher water retention capacity, which in turn allows organic matter to be more strongly trapped (Langston and Ridgway, 2006). Given our results, we consider that for the study area at Culatra island, sediment type, plant species, or even a shared effect of both, are not determinant for the identity of the rhizobiomes.

The rhizobiome class composition of seagrasses in France described in this study corresponds well with that previously reported for a Zostera noltii-colonized sediment from Bassin d'Arcachon, Southwestern France, which was dominated by Deltaproteobacteria (36\%) and Gammaproteobacteria (27\%) based on 16S rRNA gene cloning (Cifuentes et al., 2000). When comparing the rhizobiomes of Zostera spp. between Portugal and France, we observed significant differences between both locations. According to the hologenome theory of evolution, the diverse and abundant consortium of microorganisms evolves in association with their host as one single entity, but is susceptible to (fast) variations if a change is brought into the system via host genome or microbiome (Rosenberg et al., 2007; Zilber-Rosenberg and Rosenberg, 2008). On sight of our results, we consider that the rhizobiome is a part of the seagrass holobiont, and that at a local scale its selection is driven by the host, whereas at large scale/long distance, the selection is more strongly shaped by the environment. This is supported by the presence of similar rhizobiomes within Portugal, although their sediment characteristics significantly differ, concomitantly with the presence of differences between the rhizobiomes of Portugal and France, despite the similarities in their sediment characteristics.

\section{Core Seagrass Rhizobiome}

The top five most abundant core OTUs (abundance between 5 and $10 \%$ of the core rhizobiome) were classified as members of five different classes, Epsilonproteobacteria (family Helicobacteraceae), Acidimicrobiia (family koll13), Gammaproteobacteria (order Chromatiales), Deltaproteobacteria (genus Desulfococcus), and Clostridia (order Clostridiales). Likewise, Gamma- and Deltaproteobacteria have previously been found to be among the most abundant members of the core microbiome of belowground structures in the seagrass Halophila stipulacea (Mejia et al., 2016). The Clostridiales and other core taxa belonging to the alphaproteobacterial family Rhodobacteraceae (Meyer and Kuever, 2007), the Delta- (Muyzer and Stams, 2008) and Epsilonproteobacteria (Campbell et al., 2006) classes, as well as the gammaproteobacterial orders Thiotrichales (Garrity et al., 2005) and Alteromonadales (Fuchs et al., 2007) are likely to be involved in sulfur processes, such as sulfate reduction and sulfur oxidation. Members of the order Clostridiales (Firmicutes), for instance, can be involved in sulfate reduction (Desulfotomaculum sp.; Widdel, 2006), as well as in processes such as nitrogen fixation (e.g., Clostridium pasteurianum; Chen, 2004) and fermentation (e.g., Clostridium acetobutylicum; Cato et al., 1986). One of the fermentation products of solventogenic Clostridia is acetone (Han et al., 2011), which can be completely oxidized by other bacteria, such as the sulfate-reducing Desulfococcus biacutus (Platen et al., 1990). In the present work, the genus Desulfococcus was one of the most abundant genera (specifically $7 \%$, Supplementary Table S3). This genus was represented by 5 different OTUs and although the taxonomic resolution of some of the core OTUs was very low, the data indicated this as the most diverse genus in the core. Members of Desulfococcus are important hydrocarbon degraders (Miralles et al., 2007; Apostolopoulou et al., 2014). Their high abundance and diversity in the core rhizobiome of seagrasses might function as a buffer between contaminated sediments and the plants, thereby detoxifying the root area from these phytotoxic compounds (Saxe, 1996).

Comprising 21 OTUs and ranking as the second most diverse and abundant phylum (14.7\%) in the core seagrass rhizobiome are the Bacteroidetes that are known to be widespread across marine environments, including sediments (e.g., Khan et al., 2007). Within this phylum, the cluster CytophagaFlavobacteria is highly abundant and one of the most represented groups in aquatic ecosystems (Kirchman, 2002). They are important decomposers of high molecular weight organic matter (Kirchman, 2002), such as cellulose and chitin (Fenchel, 2012).

Actinobacteria are common inhabitants of roots of terrestrial plants, where they might function as biocontrol agents against pathogens (e.g., Ting et al., 2009). However, little is known about 


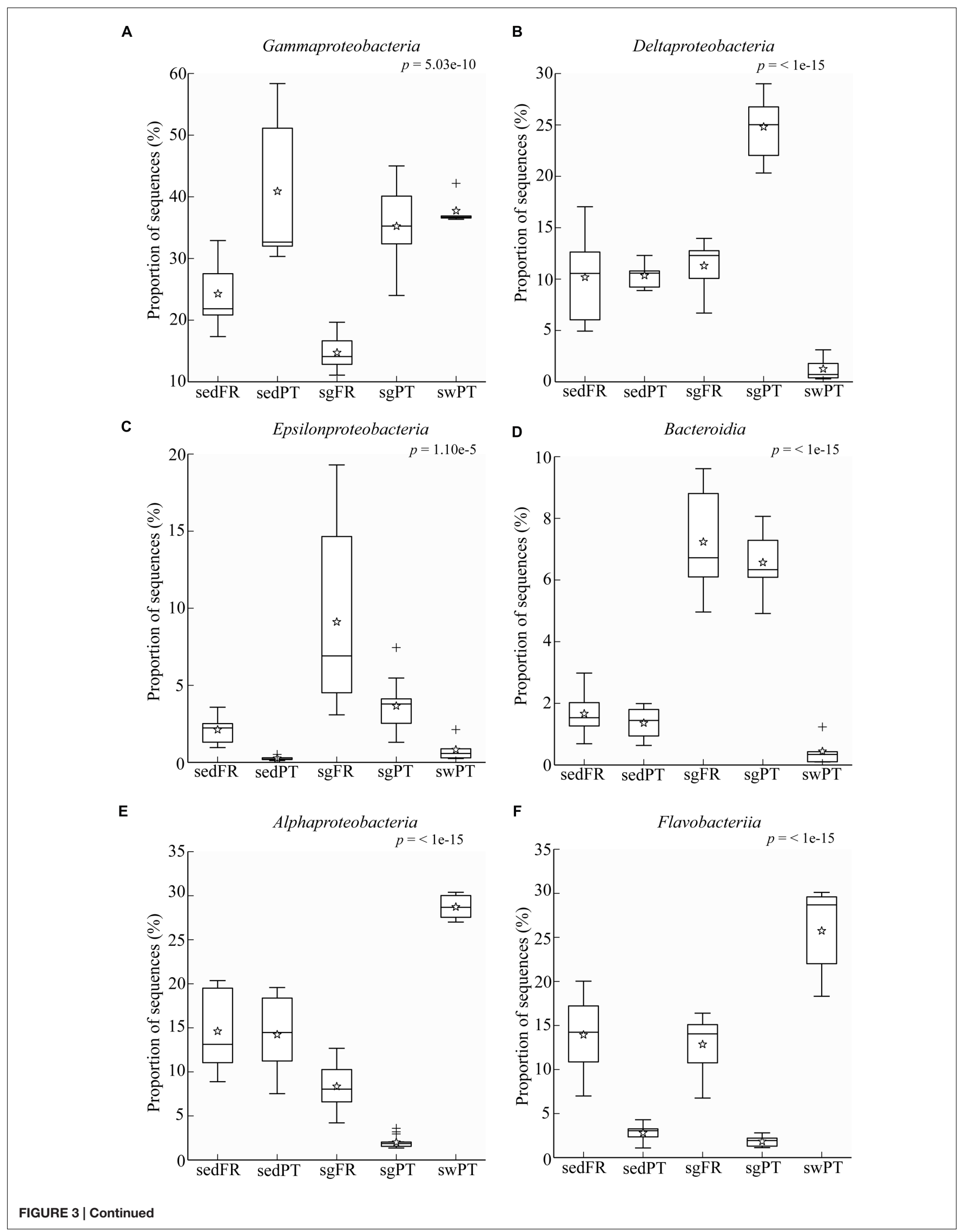




\section{FIGURE 3 | Continued}

Box plots showing the relative abundance of sequences of the most abundant groups in the rhizobiome of seagrasses from Portugal and France, and the bacterial communities from the surrounding environment. Indicated are bulk sediments from Portugal (sedPT) and France (sedFR); seagrasses from Portugal (sgPT) and France (sgFR); seawater from Portugal (swPT). The top of the box indicates the third quartile, the bottom the first quartile, and the line in the middle is the median. The star indicates the mean of the data, crosses are outliers, and the whiskers represent error bars. (A) Gammaproteobacteria,

(B) Deltaproteobacteria, (C) Epsilonproteobacteria, (D) Bacteroidia, (E) Alphaproteobacteria, and (F) Flavobacteriia.

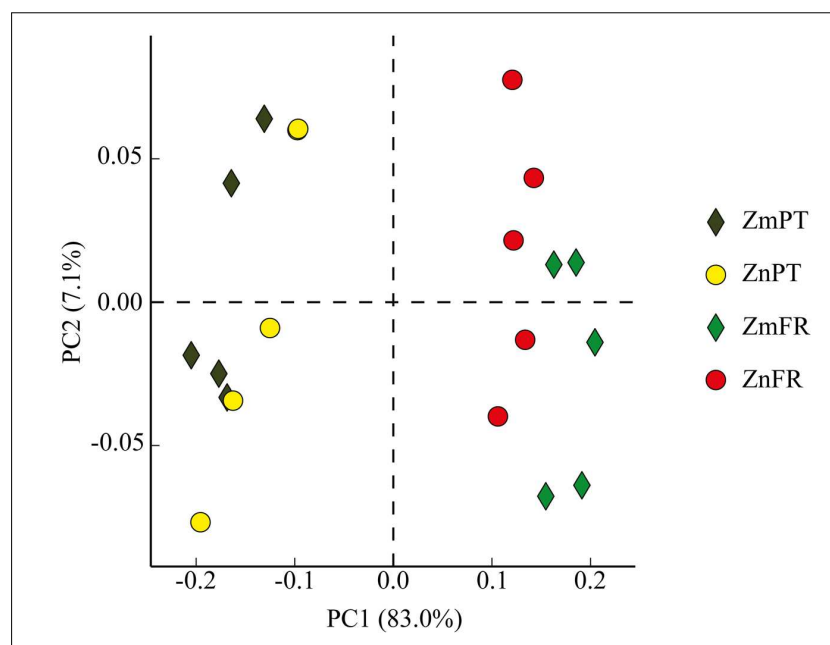

FIGURE 4 | Principal component analysis (PCA) plot comparing bacterial communities of the rhizosphere of the seagrasses $Z$. marina (Zm) and Z. noltii (Zn), from Portugal (PT) and France (FR). Percentage of community variance explained by each axis is indicated in parentheses.

their presence and function in the rhizosphere of seagrasses (Ravikumar et al., 2012; Wu et al., 2012; Jose et al., 2014). Here we found that 7 OTUs ( $9 \%$ of the core taxa present in the studied seagrasses) belonged to this phylum, possibly specifically recruited by the plant in order to provide protection against pathogens, therefore facilitating its immune responses (Cook et al., 1995; Mendes et al., 2011).

Although many functions of the abovementioned taxa have already been described, the ecological role of members of some of these phyla, such as Acidobacteria, Caldithrix, Chloroflexi, and Gemmatimonadetes to the seagrass rhizobiome is unclear. This is mainly due to the small number of strains that have been isolated and characterized. In some cases, their role is completely unknown, because cultured representatives are lacking, which is the case for members of the phylum WS3. Nevertheless, it is possible to infer putative roles of some members of these taxa. Members of WS3 for instance, have been consistently detected in sediments (e.g., Ikenaga et al., 2010; Zeng et al., 2010), and the genus KSB4, in particular, was previously identified in sulfide-rich sediments of coastal environments (Tanner et al., 2000), which might indicate a possible role in the sulfur cycle. The first cultured representative of the phylum Gemmatimonadetes, Gemmatimonas aurantiaca, was isolated from an anaerobic-aerobic sequential batch reactor used for enhanced biological phosphorus removal from wastewater. The strain could accumulate polyphosphate and so might be involved in the phosphorus cycle. DeBruyn et al. (2011) studied the ecology of the Gemmatimonadetes and found that it was ubiquitously present in soil. Acidobacteria are frequently
A

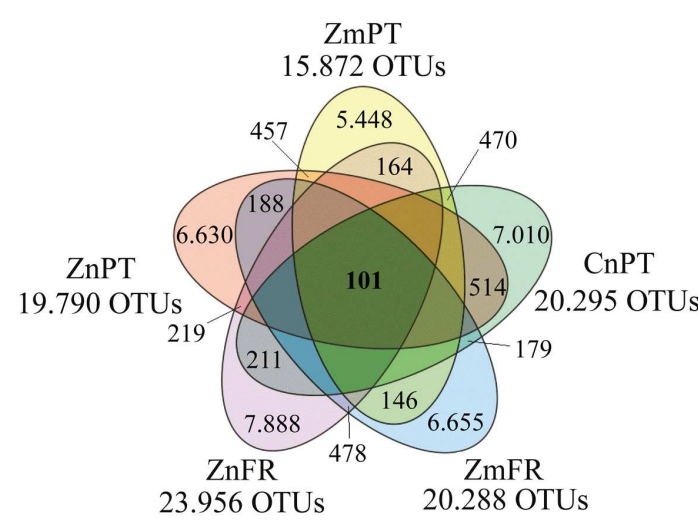

\begin{tabular}{|lcr|}
\hline \multicolumn{3}{|c|}{ Core rhizobiome } \\
\hline \multicolumn{1}{|c|}{ Phylum } & \# OTUs & $\%$ \\
\hline Acidobacteria & 5 & 1.65 \\
Actinobacteria & 7 & 8.80 \\
Bacteroidetes & 21 & 14.70 \\
Caldithrix & 1 & 0.59 \\
Chloroflexi & 2 & 0.38 \\
Firmicutes & 2 & 7.41 \\
Gemmatimonadetes & 1 & 0.48 \\
Proteobacteria & 59 & 64.20 \\
WS3 & 3 & 1.04 \\
TOTAL & $\mathbf{1 0 1}$ \\
\hline
\end{tabular}

FIGURE 5 | Venn diagram showing the core rhizobiome of all seagrasses studied. (A) Zostera marina (Zm-), Z. noltii (Zn-), both from Portugal (-PT) and France (-FR), and C. nodosa from Portugal (CnPT). The total number of OTUs clustered at a similarity level of $97 \%$ is represented under the label of each sample. The number of unique OTUs and OTUs shared between each combination of two samples is also shown. (B) Summarized taxonomic composition of the core rhizobiome, and respective number of OTUs present in each phylum. The relative number of the OTUs present in each phylum is also shown, indicated as percentage of sequences. A complete overview of the identity of the 101 OTUs that comprise the core rhizobiome of seagrasses is presented in Supplementary Table S3. 
A

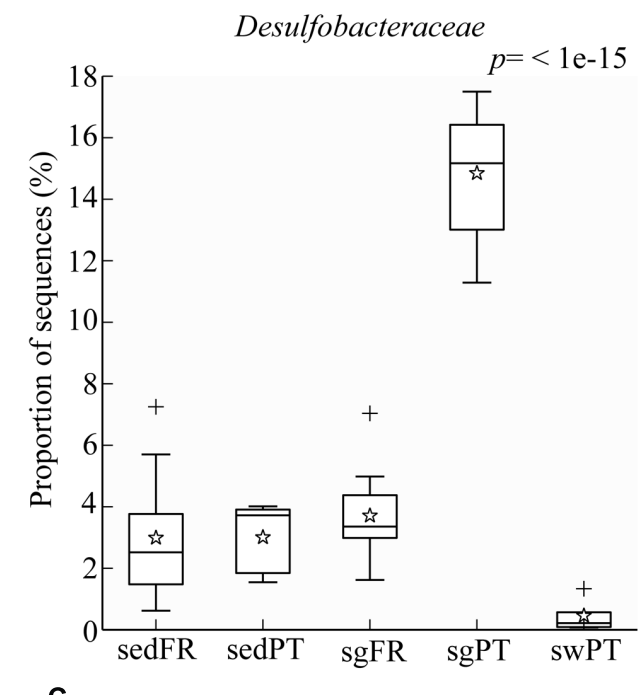

C
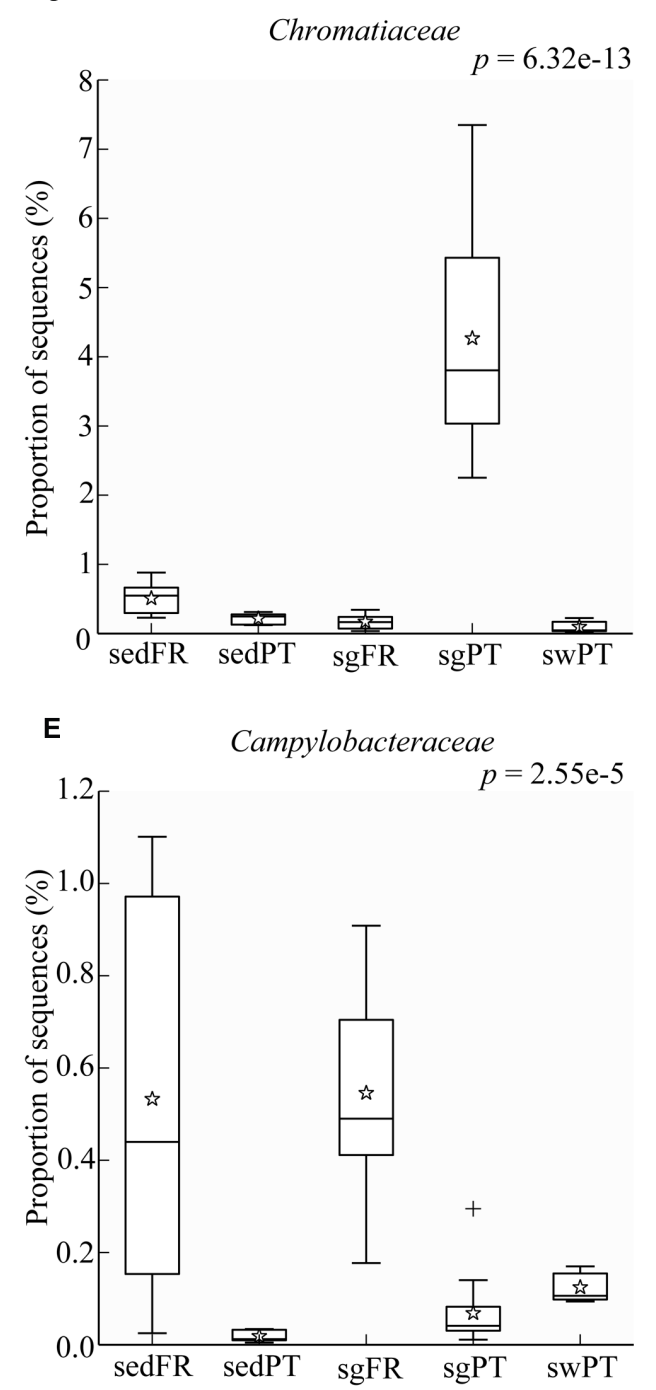

B

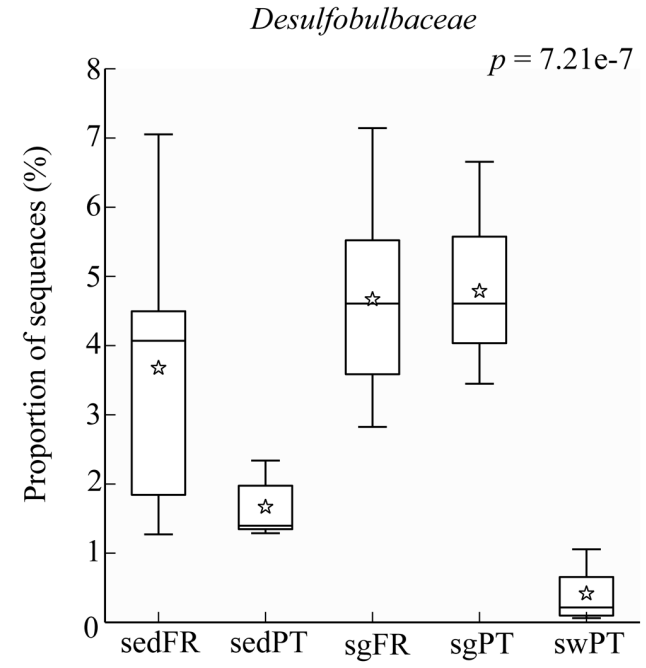

D

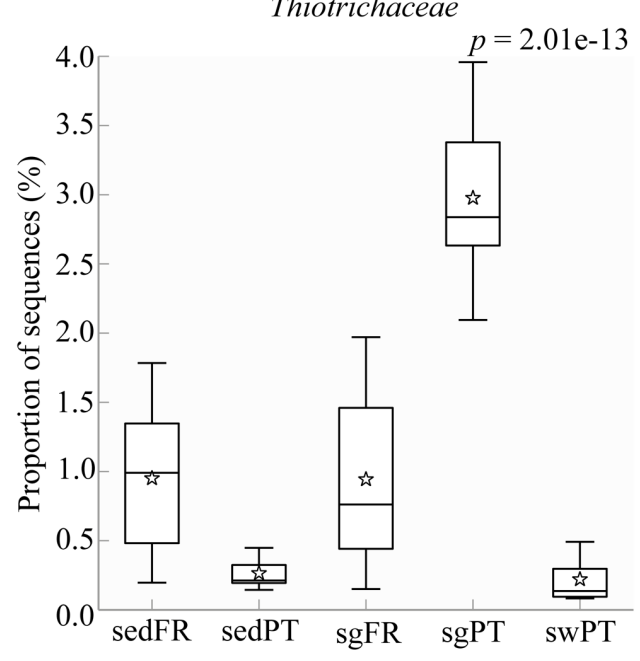

F

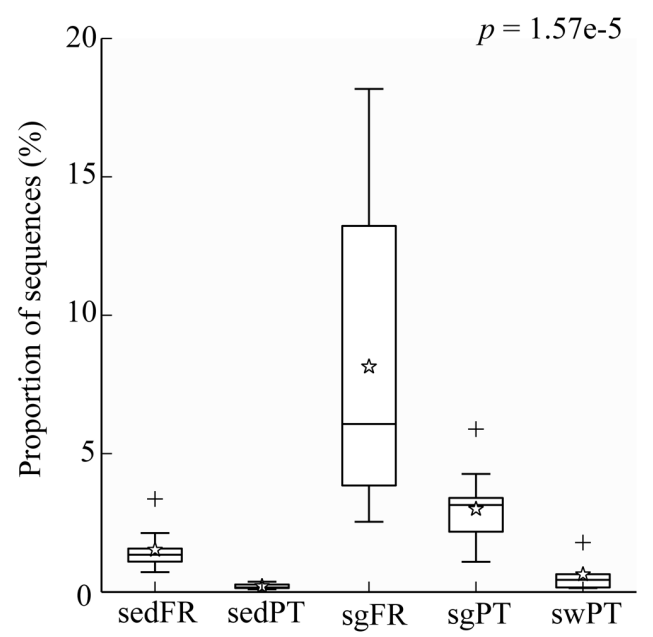

FIGURE 6 | Continued 


\section{FIGURE 6 | Continued}

Box plots showing the relative abundance of sequences of the most abundant bacterial groups involved in sulfur processes. (A) Desulfobacteraceae, (B) Desulfobulbaceae, (C) Chromatiaceae, (D) Thiotrichaceae, (E) Campylobacteraceae, and (F) Helicobacteraceae. Indicated are bulk sediments from Portugal (sedPT) and France (sedFR); seagrasses from Portugal (sgPT) and France (sgFR); seawater from Portugal (swPT). The top of the box indicates the third quartile, the bottom the first quartile, and the line in the middle is the median. The star indicates the mean of the data, crosses are outliers, and the whiskers represent error bars.

abundant in sediments and soils, and although they have very few isolated members, the genome analysis of three strains from this phylum performed by Ward et al. (2009) suggests that these bacteria might be involved in the production of antimicrobial compounds, stabilization of the soil structure, and also in the degradation of complex sugars such as chitin, which highlights the possible importance of these bacteria in the carbon cycling in marine biomes.

The identification of the core rhizobiome provides insights into key host-microbe interactions, by detecting which bacteria consistently inhabit the rhizosphere, thereby stressing their potential importance in the maintenance of a healthy seagrass holobiont. Even though the percentage of some of the individual core OTUs was low (Supplementary Table S3), their activity is likely to be higher than more abundant OTUs, as previously reported in comparisons between rare biosphere and common OTUs from different environments (reviewed by Lynch and Neufeld, 2015). Identifying these taxa provides important cues for the understanding of the phylogenetic (and potentially functional) identity of the consortium of bacteria inhabiting the seagrass rhizosphere. By identifying the core microbiome among three seagrass species in two different locations, we covered the spatial dynamism regardless of differences caused by different "hosts" in a biogeographical framework. Moreover, the detection of genera like Desulfococcus, which harbored 5 different OTUs (clustered at $97 \%$ similarity) whereas only 2 species have been described in the literature (Kuever et al., 2005b), together with all the unclassified OTUs widespread among the remaining taxa, indicates that the rhizosphere recruits a widely unknown variety of microorganisms potentially essential for the plants.

The role of the core taxa identified in this study is likely to go beyond its importance for the seagrasses. Bacteria like Clostridium sp. (Wagner and Stadtman, 1962) and Desulfovibrio sp. (van der Maarel et al., 1996), both present in the core, are able to degrade the osmoprotectant dimethylsulfoniopropionate (DMSP) into dimethylsulfide (DMS; reviewed in Yoch, 2002). DMSP is produced by micro- and macroalgae, as well as by seagrasses, and is highly abundant in marine sediments (Jonkers et al., 2000). One of the end products of this cleavage process is DMS, which is a volatile organic sulfur compound that has the ability to control global climate by enhancing the albedo and formation of clouds in the atmosphere (Shaw, 1983; Charlson et al., 1987). Therefore, the core seagrass rhizobiome might play a pivotal role in climate change by harboring bacteria directly involved in DMS formation.

\section{Niche Differentiation of Sulfur Bacteria}

Sulfate reduction is one of the main processes in marine sediments (Jørgensen, 1982), but in particular in seagrass meadows where it is fuelled by exudates from the plant roots (Isaksen and Finster, 1996; Holmer and Nielsen, 1997; Hansen et al., 2000). The class Deltaproteobacteria was represented predominantly by members of the family Desulfobacteraceae in the rhizobiomes of seagrasses collected from Portugal, and by Desulfobulbaceae in both France and Portugal (Figures 6A,B). The most dominant members of the Desulfobacteraceae in the rhizobiomes of seagrasses from Portugal were affiliated to the genus Desulfococcus and to a lesser extent to Desulfosarcina. Members of these genera use sulfate, sulfite, and thiosulfate as electron acceptors to oxidize different fatty acids and alcohols completely to $\mathrm{CO}_{2}$ (Brysch et al., 1987). The dominant members within the Desulfobulbaceae were uncultured lineages and Desulfocapsa. In general, members belonging to the Desulfobulbaceae use sulfate, sulfite, and thiosulfate as electron acceptors to oxidize different fatty acids incompletely to acetate (Kuever et al., 2005c). In addition, Desulfocapsa can also disproportionate thiosulfate and elemental sulfur to $\mathrm{H}_{2} \mathrm{~S}$ and sulfate (Finster et al., 1998). Like genera belonging to the Desulfobacteraceae family, Desulfocapsa are also able to oxidize alcohols. During the night cycle, the lack of oxygen around the roots leads seagrass root tissues to switch to fermentation, which causes the release of ethanol to the rhizosphere (Smith et al., 1988). This association might represent a fair trade between host and microbe, in which during the night bacteria use ethanol as electron donor to remove this alcohol from the surrounding of the roots (Kuever et al., 2005a) although during light conditions they release hydrogen sulfide. The versatility of bacteria able to perform both sulfate reduction and elemental sulfur and thiosulfate disproportionation can be a very advantageous feature to the seagrass-microbe interactions occurring in the rhizosphere.

Sulfide, which is highly toxic to seagrasses, can be neutralized by the activity of sulfur-oxidizing bacteria. Joshi and Hollis (1977) described the protection of rice seedlings from $\mathrm{H}_{2} \mathrm{~S}$ by the colorless sulfur-oxidizing gammaproteobacterium Beggiatoa. Recently, van der Heide et al. (2012) nicely demonstrated that sulfide-oxidizing bacteria in the gills of the lucinid bivalve Loripes lacteus could reduce sulfide stress for the seagrass Zostera noltii. However, they also found that $Z$. noltii without bivalves could to some extent also reduce the sulfide concentration, which might be the result of the seagrass (Hasler-Sheetal and Holmer, 2015) and indigenous sulfur-oxidizing bacteria in the rhizosphere of the seagrass. In our sediments, Loripes or related lucinid bivalves were absent, and so sulfur-oxidizing bacteria of the Gamma- and/or Epsilonproteobacteria probably contributed to detoxification of sulfide. These bacteria were represented by Chromatiaceae and Thiotrichaceae of the Gammaproteobacteria in the rhizobiomes of seagrasses from Portugal (Figures 6C,D), 
while members of the Campylobacteraceae and Helicobacteraceae both belonging to the Epsilonproteobacteria were mainly found in the rhizobiomes of seagrasses collected in France (Figures 6E,F). Although Chromatiaceae are predominantly phototrophic, some of them might be able to colonize the rhizosphere by switching their growth strategy to chemo-, organo-, and/or mixotrophy, according to the environmental conditions (e.g., Madigan and Gest, 1979; Kämpf and Pfennig, 1980). The most dominant genus within the Helicobacteraceae was Sulfurimonas, while members of the genera Arcobacter and Sulfurospirillum, both belonging to the Campylobacteraceae, were present at lower numbers. Similar results were obtained by Jensen et al. (2007), who found a dominance of sulfur-oxidizing bacteria affiliated to the Epsilonproteobacteria, such as Arcobacter and Sulfurimonas in the rhizosphere of $Z$. marina in Denmark. Thomas et al. (2014), who studied the abundance and activity of sulfur-oxidizing bacteria in salt marsh sediments colonized by the plant Spartina alterniflora, found a predominance of sulfur-oxidizing bacteria of the Gammaproteobacteria (Chromatiales and Thiotrichales) and to a lesser extend Alpha- and Epsilonproteobacteria.

This study shows that the seagrass rhizosphere is dominated by bacteria involved in the sulfur cycle, and it strongly suggests that, regardless their phylogenetic affiliation, the functionality of bacteria related to sulfur processes is maintained across different regions. At a small scale/short distance, seagrass rhizobiomes are shaped by the plant (although not at a host species level), and at a large scale/long distance level, they are shaped by environmental differences, extrinsic to plant phylogeny. Furthermore, our results suggest that sediment grain size and percentage of organic matter are not determinant for the microbial structure of the seagrass rhizobiomes at Culatra island, therefore further (experimental) research is required in order to reveal the parameters exerting the environmental pressure observed across regions.

\section{REFERENCES}

Agostini, S., Desjobert, J. M., and Pergent, G. (1998). Distribution of phenolic compounds in the seagrass Posidonia oceanica. Phytochemistry 48, 611-617. doi: 10.1016/S0031-4989422(97) 01118-7

Apostolopoulou, M. V., Monteyne, E., Krikonis, K., Pavlopoulos, K., Roose, P., and Dehairs, F. (2014). Monitoring polycyclic aromatic hydrocarbons in the Northeast Aegean Sea using Posidonia oceanica seagrass and synthetic passive samplers. Mar. Pollut. Bull. 87, 338-344. doi: 10.1016/j.marpolbul.2014. 07.051

Asmus, R. M., Sprung, M., and Asmus, H. (2000). Nutrient fluxes in intertidal communities of a South European lagoon (Ria Formosa) similarities and differences with a northern Wadden Sea bay (SyltRømø Bay). Hydrobiologia 436, 217-235. doi: 10.1023/A:102654 2621512

Bachelet, G., Guillou, J., and Labourg, P. J. (1992). "Adult-larval and juvenile interactions in the suspension-feeding bivalve, Cerastoderma edule (L.): field observations and experiments," in Marine Eutrophication and Population Dynamics, eds G. Colombo, I. Ferrari, V. U. Ceccherelli, and R. Rossi (Fredensborg: Olsen \& Olsen), $175-182$.

Berendsen, R. L., Pieterse, C. M. J., and Bakker, A. H. M. (2012). The rhizosphere microbiome and plant health. Trends Plant Sci. 17, 478-486. doi: 10.1016/j.tplants.2012.04.001

\section{AUTHOR CONTRIBUTIONS}

CC, AE, and GM designed the study and collected the samples. CC performed lab-experiments and data analysis. $\mathrm{CC}$ wrote the manuscript and all authors contributed to the discussion of the results and to the final version of the manuscript.

\section{FUNDING}

This work was supported by grants from the European Union (MaCuMBA and ASSEMBLE 8) to GM and CC, and fellowships SFRH/BPD/63/03/2009 and SFRH/BPD/107878/2015 of Fundação para a Ciência e a Tecnologia (FCT) to AE.

\section{ACKNOWLEDGMENTS}

We thank Christian Jeanthon for collecting samples from Roscoff, and Vincent Ouisse for providing us with detailed information regarding sediment characteristics from Roscoff. We thank Emily D. Melton for critically reading the manuscript, and Tim Piel for his collaboration in collecting sediments from Portugal, as well as in the sediment analysis.

\section{SUPPLEMENTARY MATERIAL}

The Supplementary Material for this article can be found online at: http://journal.frontiersin.org/article/10.3389/fmicb. 2016.00440

Berg, G., and Smalla, K. (2009). Plant species and soil type cooperatively shape the structure and function of microbial communities in the rhizosphere. FEMS Microbiol. Ecol. 68, 1-13. doi: 10.1111/j.1574-6941.2009.00654.x

Blaabjerg, V., and Finster, K. (1998). Sulphate reduction associated with roots and rhizomes of the marine macrophyte Zostera marina. Aquat. Microb. Ecol. 15, 311-314. doi: 10.3354/ame015311

Borum, J., Pedersen, O., Greve, T. M., Frankovich, T. A., Zieman, J. C., Fourqurean, J. W., et al. (2005). The potential role of plant oxygen and sulphide dynamics in die-off events in tropical seagrass, Thalassia testudinum. J. Ecol. 93, 148-158. doi: 10.1111/j.1365-2745.2004.00943.x

Brysch, K., Schneider, C., Fuchs, G., and Widdel, F. (1987). Lithoautotrophic growth of sulfate-reducing bacteria, and description of Desulfobacterium autotrophicum gen. nov., sp. nov. Arch. Microbiol. 148, 264-274. doi: 10.1007/BF00456703

Buesing, N., and Gessner, M. O. (2002). Comparison of detachment procedures for direct counts of bacteria associated with sediment particles, plant litter and epiphytic biofilms. Aquat. Microb. Ecol. 27, 29-36. doi: 10.3354/ame027029

Bulgarelli, D., Rott, M., Schlaeppi, K., Van Themaat, E. V. L., Ahmadinejad, N., Assenza, F., et al. (2012). Revealing structure and assembly cues for Arabidopsis root-inhabiting bacterial microbiota. Nature 488, 91-95. doi: 10.1038 /nature 11336

Bulgarelli, D., Schlaeppi, K., Spaepen, S., Van Themaat, E. V. L., and SchulzeLefert, P. (2013). Structure and functions of the bacterial microbiota of plants. Annu. Rev. Plant Biol. 64, 807-838. doi: 10.1146/annurev-arplant-050312120106 
Cabaço, S., and Santos, R. (2010). Reproduction of the eelgrass Zostera marina at the species southern distributional limit in the Eastern Atlantic. Mar. Ecol. 31, 300-308. doi: 10.1111/j.1439-0485.2009.00331.x

Campbell, B. J., Engel, A. S., Porter, M. L., and Takai, K. (2006). The versatile E-proteobacteria: key players in sulphidic habitats. Nat. Rev. Microbiol. 4, 458468. doi: $10.1038 /$ nrmicro1414

Capone, D. G., and Kiene, R. P. (1988). Comparison of microbial dynamics in marine and freshwatersediments: contrasts in anaerobic carbon metabolism. Limnol. Oceanogr. 33, 725-749. doi: 10.4319/lo.1988.33.4_part_2.0725

Caporaso, J. G., Bittinger, K., Bushman, F. D., DeSantis, T. Z., Andersen, G. L., and Knight, R. (2010a). PyNAST: a flexible tool for aligning sequences to a template alignment. Bioinformatics 26, 266-267. doi: 10.1093/bioinformatics/ btp636

Caporaso, J. G., Kuckynsky, J., Stombaugh, J., Bittinger, K., Bushman, F. D., Costello, E. K., et al. (2010b). QIIME allows analysis of highthroughput community sequencing data. Nat. Methods 7, 335-336. doi: 10.1038/nmeth.f.303

Cato, E. P., George, W. L., and Finegold, S. M. (1986). “Genus Clostridium," in Bergey's Manual of Systematic Bacteriology, ed. P. H. A. Sneath (Baltimore: Williams and Wilkins), 1141-1200.

Chaparro, J. M., Badri, D. V., and Vivanco, J. M. (2014). Rhizosphere microbiome assemblage is affected by plant development. ISME J. 8, 790-803. doi: 10.1038/ismej.2013.196

Charlson, R. J., Lovelock, J. E., Andreae, M. O., and Warren, S. G. (1987). Oceanic phytoplankton, atmospheric sulphur, cloud albedo and climate. Nature 326, 655-661. doi: 10.1038/326655a0

Chen, J.-S. (2004). "Nitrogen fixation in Clostridia," in Genetics and Regulation of Nitrogen Fixation in Free-Living Bacteria, eds W. Klipp, B. Masepohl, J. R. Gallon, and W. E. Newton (Dordrecht: Kluwer Academic Publishers), 53-62.

Cifuentes, A., Antón, J., Benlloch, S., Donnelly, A., Herbert, R. A., and Rodríguez-Valera, F. (2000). Prokaryotic diversity in Zostera noltiicolonized marine sediments. Appl. Environ. Microbiol. 66, 1715-1719. doi: 10.1128/AEM.66.4.1715-1719.2000

Cifuentes, A., Antón, J., De Wit, R., and Rodríguez-Valera, F. (2003). Diversity of Bacteria and Archaea in sulphate-reducing enrichment cultures inoculated from serial dilution of Zostera noltii rhizosphere samples. Environ. Microbiol. 5, 754-764. doi: 10.1046/j.1462-920.2003.00470.x

Clarke, K. R. (1993). Non-parametric multivariate analyses of changes in community structure. Aust. J. Ecol. 18, 117-143. doi: 10.1111/j.14429993.1993.tb00438.x

Cook, R. J., Thomashow, L. S., Weller, D. M., Fujimoto, D., Mazzola, M., Bangera, G., et al. (1995). Molecular mechanisms of defense by rhizobacteria against root disease. Proc. Natl. Acad. Sci. U.S.A. 92, 4197-4201. doi: 10.1073/pnas.92.10.4197

Costa, R., Gotz, M., Mrotzek, N., Lottmann, J., Berg, G., and Smalla, K. (2006). Effects of site and plant species on rhizosphere community structure as revealed by molecular analysis of microbial guilds. FEMS Microbiol. Ecol. 56, 236-249. doi: 10.1111/j.1574-6941.2005.00026.x

Crump, B. C., and Koch, E. W. (2008). Attached bacterial populations shared by four species of aquatic angiosperms. Appl. Environ. Microbiol. 74, 5948-5957. doi: 10.1128/AEM.00952-08

Dean, W. E. (1974). Determination of carbonate and organic matter in calcareous sediments and sedimentary rocks by loss on ignition; comparison with other methods. J. Sediment. Res. 44, 242-248. doi: 10.1306/74D729D2-2B21-11D7$8648000102 \mathrm{C} 1865 \mathrm{D}$

DeBruyn, J. M., Nixon, L. T., Fawaz, M. N., Johnson, A. M., and Radosevich, M. (2011). Global biogeography and quantitative seasonal dynamics of Gemmatimonadetes in soil. Appl. Environ. Microbiol. 77, 6295-6300. doi: 10.1128/AEM.05005-11

den Hartog, C., and Kuo, J. (2006). “Taxonomy and biogeography of seagrasses," in Seagrass: Biology, Ecology and Conservation, eds A. W. D. Larkum, R. J. Orth, and C. M. Duarte (Dordrecht: Springer), 1-23.

Devereux, R. (2005). "Seagrass rhizosphere microbial communities," in Interactions Between Macro- and Microorganisms in Marine Sediments, eds E. Kristensen, R. R. Haese, and J. E. Kostka (Washington, DC: American Geophysical Union), 199-216.

Duarte, C. M., Holmer, M., and Marba, N. (2005a). "Plant-microbe interactions in seagrass meadows," in Interactions Between Macro- and Microorganisms in
Marine Sediments, eds E. Kristensen, R. R. Haese, and J. E. Kostka (Washington, DC: American Geophysical Union), 31-60.

Duarte, C. M., Middelburg, J. J., and Caraco, N. (2005b). Major role of marine vegetation on the oceanic carbon cycle. Biogeosciences 2, 1-8. doi: 10.5194/bg2-1-2005

Edgar, R. C. (2010). Search and clustering orders of magnitude faster than BLAST. Bioinformatics 26, 2460-2461. doi: 10.1093/bioinformatics/btq461

Egamberdieva, D., Kamilova, F., Validov, S., Gafurova, L., Kucharova, Z., and Lugtenberg, B. (2008). High incidence of plant growth-stimulating bacteria associated with the rhizosphere of wheat grown on salinated soil in Uzbekistan. Environ. Microbiol. 10, 1-9. doi: 10.1111/j.1462-2920.2007.01424.x

Falcão, M., and Vale, C. (1990). Study of the Ria Formosa ecosystem: benthic nutrient remineralization and tidal variability of nutrients in the water. Hydrobiologia 207, 137-146. doi: 10.1007/BF00041450

Fenchel, T. (2012). "Degradation of organic polymers and hydrocarbons," in Bacterial Biogeochemistry: The Ecophysiology of Mineral Cycling, eds T. Fenchel, G. King, and H. Blackburn (San Diego, CA: Academic press), 49-57.

Finster, K., Liesack, W., and Thamdrup, B. (1998). Elemental sulfur and thiosulfate disproportionation by Desulfocapsa sulfoexigens sp. nov., a new anaerobic bacterium isolated from marine surface sediment. Appl. Environ. Microbiol. 64, 119-125.

Fonseca, M. S., Julius, B. E., and Kenworthy, W. J. (2000). Integrating biology and economics in seagrass restoration: how much is enough and why? Ecol. Eng. 15, 227-237. doi: 10.1016/S0925-8574(00)00078-1

Fourqurean, J. W., Duarte, C. M., Kennedy, H., Marbà, N., Holmer, M., Mateo, M. A., et al. (2012). Seagrass ecosystems as a globally significant carbon stock. Nat. Geosci. 5, 505-509. doi: 10.1038/ngeo1477

Fuchs, B. M., Spring, S., Teeling, H., Quast, C., Wulf, J., Schattenhofer, M., et al. (2007). Characterization of a marine gammaproteobacterium capable of aerobic anoxygenic photosynthesis. Proc. Natl. Acad. Sci. U.S.A. 104, 2891-2896. doi: 10.1073/pnas.0608046104

Gacia, E., Granata, T. C., and Duarte, C. M. (1999). An approach to measurement of particle flux and sediment retention within seagrass (Posidonia oceanica) meadows. Aquat. Bot. 65, 255-268. doi: 10.1016/S0304-3770(99) 00044-3

Garrity, G. M., Bell, J. A., and Lilburn, T. (2005). “Order V. Thiotrichales ord. nov," in Bergey's Manual of Systematic Bacteriology, (The Proteobacteria), Part B (TheGammaproteobacteria), Vol. 2, eds D. J. Brenner, N. R. Krieg, J. T. Staley, and G. M. Garrity (New York, NY: Springer), 131.

Hammer, Ø., Haeper, D. A. T., and Ryan, P. D. (2001). PAST: paleontological statistics software package for education and data analysis. Palaeontol. Electron. $4: 9$

Han, B., Gopalan, V., and Ezeji, T. C. (2011). Acetone production in solventogenic Clostridium species: new insights from non-enzymatic decarboxylation of acetoacetate. Appl. Microbiol. Biotechnol. 91, 565-576. doi: 10.1007/s00253-0113276-5

Hansen, J. W., Udy, J. W., Perry, C. J., Dennison, W. C., and Lomstein, B. A. (2000). Effect of the seagrass Zostera capricorni on sediment microbial processes. Mar. Ecol. Prog. Ser. 199, 83-96. doi: 10.3354/meps199083

Hasler-Sheetal, H., and Holmer, M. (2015). Sulfide intrusion and detoxification in the seagrass Zostera marina. PLoS ONE 10:e129136. doi: 10.1371/journal.pone.0129136

Heglmeier, A., and Zidorn, C. (2010). Secondary metabolites of Posidonia oceanica (Posidoniaceae). Biochem. Syst. Ecol. 38, 964-970. doi: 10.1016/j.bse.2010.07.001

Herlemann, D. P. R., Labrenz, M., Juergens, K., Bertilsson, S., Waniek, J. J., and Andersson, A. F. (2011). Transitions in bacterial communities along the $2000 \mathrm{~km}$ salinity gradient of the Baltic Sea. ISME J. 5, 1571-1579. doi: 10.1038/ismej.2011.41

Holme, N. A., and McIntyre, A. D. (1984). Methods for the Study of Marine Benthos. London: Blackwell Scientific Publication.

Holmer, M., and Nielsen, S. L. (1997). Sediment sulfur dynamics related to biomass-density patterns in Zostera marina (eelgrass) beds. Mar. Ecol Prog. Ser. 146, 163-171. doi: 10.3354/meps146163

Ikenaga, M., Guevara, R., Dean, A. L., Pisani, C., and Boyer, J. N. (2010). Changes in community structure of sediment bacteria along the florida coastal everglades march-mangrove-seagrass salinity gradient. Microb. Ecol. 59, 284-295. doi: 10.1007/s00248-009-9572-2 
Isaksen, M. F., and Finster, K. (1996). Sulphate reduction in the root zone of the seagrass Zostera noltii on the intertidal flats of a coastal lagoon (Arcachon, France). Mar. Ecol. Prog. Ser. 137, 187-194. doi: 10.3354/meps137187

James, J. B., Sherman, T. D., and Devereux, R. (2006). Analysis of bacterial communities in seagrass bed sediments by double-gradient denaturing gradient gel electrophoresis of PCR-amplified 16S rRNA genes. Microbial Ecol. 52, 655-661. doi: 10.1007/s00248-006-9075-3

Jensen, S. I., Kühl, M., and Priemé, A. (2007). Different bacterial communities associated with the roots and bulk sediment of the seagrass Zostera marina. FEMS Microbiol. Ecol. 62, 108-117. doi: 10.1111/j.1574-6941.2007.00373.x

Jonkers, H. M., Van Bergeijk, S. A., and Van Gemerden, H. (2000). Microbial production and consumption of dimethyl sulfide (DMS) in a sea grass (Zostera noltii)-dominated marine intertidal sediment ecosystem (Bassin d'Arcachon, France). FEMS Microbiol. Ecol. 31, 163-172. doi: 10.1111/j.15746941.2000.tb00681.x

Jørgensen, B. B. (1982). Mineralization of organic matter in the sea bed - the role of sulphate reduction. Nature 296, 643-645. doi: 10.1038/296643a0

Jose, P. A., Sundari, I. S., Sivakala, K. K., and Jebakumar, S. R. D. (2014). Molecular phylogeny and plant growth promoting traits of endophytic bacteria isolated from roots of seagrass Cymodocea serrulata. Indian J. Geomarine Sci. 43, 571-579.

Joshi, M. M., and Hollis, J. P. (1977). Interaction of Beggiatoa and rice plant: detoxification of hydrogen sulfide in the rice rhizosphere. Science 195, 179-180. doi: 10.1126/science.195.4274.179

Kämpf, C., and Pfennig, N. (1980). Capacity of Chromatiaceae for chemotrophic growth. Specific respiration rates of Thiocystis violaceae and Chromatium vinosum. Arch. Microbiol. 127, 125-135. doi: 10.1007/BF00428016

Kennedy, H., Beggins, J., Duarte, C. M., Fourqurean, J. W., Holmer, M., Marbà, N., et al. (2010). Seagrass sediments as a global carbon sink: isotopic constraints. Global Biogeochem. Cycles 24:GB4026. doi: 10.1029/2010GB 003848

Khan, S. T., Nakagawa, Y., and Harayama, S. (2007). Sediminitomix flava gen. nov., sp. nov., of the phylum Bacteroidetes, isolated from marine sediment. Int. J. Syst. Evol. Microbiol. 57, 1689-1693. doi: 10.1099/ijs.0.64854-0

Kirchman, D. L. (2002). The ecology of Cytophaga-Flavobacteria in aquatic environments. FEMS Microbiol. Ecol. 39, 91-100. doi: 10.1111/j.15746941.2002.tb00910.x

Kloepper, J. W., and Schroth, M. N. (1979). Plant-growth promoting rhizobacteria - evidence that the mode of action involves root microflora interactions. Phytopathology 69, 1034-1034.

Koch, M. S., and Erskine, J. M. (2001). Sulfide as a phytotoxin to the tropical seagrass Thalassia testudinum: interactions with light, salinity and temperature. J. Exp. Mar. Biol. Ecol. 266, 81-95. doi: 10.1016/S0022-0981(01) 00339-2

Kozich, J. J., Westcott, S. L., Baxter, N. T., Highlander, S. K., and Schloss, P. D. (2013). Development of a dual-index sequencing strategy and curation pipeline for analysing amplicon sequence data on the MiSeq Illumina sequencing platform. Appl. Environ. Microbiol. 79, 5112-5120. doi: 10.1128/AEM. 01043-13

Krause-Jensen, D., Carstensen, J., Nielsen, S. L., Dalsgaard, T., Christensen, P. B., Fossing, H., et al. (2011). Sea bottom characteristics affect depth limits of eelgrass Zostera marina. Mar. Ecol. Prog. Ser. 425, 91-102. doi: 10.3354/meps09026

Kuever, J., Rainey, F. A., and Widdel, F. (2005a). "Genus II. Desulfocapsa," in Bergey's Manual of Systematic Bacteriology: The Proteobacteria, Part C (The Alpha-, Beta-, Delta-, and Epsilonproteobacteria), Vol. 2, eds D. J. Brenner, N. R. Krieg, J. T. Staley, and G. M. Garrity (New York, NY: Springer), 992-994.

Kuever, J., Rainey, F. A., and Widdel, F. (2005b). "Genus VI. Desulfococcus," in Bergey's Manual of Systematic Bacteriology: The Proteobacteria, Part C (The Alpha-, Beta-, Delta-, and Epsilonproteobacteria), Vol. 2, eds D. J. Brenner, N. R. Krieg, J. T. Staley, and G. M. Garrity (New York, NY: Springer), 972-974.

Kuever, J., Rainey, F. A., and Widdel, F. (2005c). "Genus X. Desulfosarcina," in Bergey's Manual of Systematic Bacteriology: The Proteobacteria, Part C (The Alpha-, Beta-, Delta-, and Epsilonproteobacteria), Vol. 2, eds D. J. Brenner, N. R. Krieg, J. T. Staley, and G. M. Garrity (New York, NY: Springer), 981-984.

Langston, W., and Ridgway, J. (2006). "Geological and geochemical influences on estuarine ecosystems," in Geology and Ecosystems, eds I. S. Zektser, B. Marker,
J. Ridgway, L. Rogachevskaya, and G. Vartanyan (New York, NY: Springer), $21-48$.

Li, H., Toubiana, M., Montfort, P., and Roch, P. (2009). Influence of temperature, salinity and E. coli tissue content on immune gene expression in mussel: results from a 2005-2008 survey. Dev. Comp. Immunol. 33, 974-979. doi: 10.1016/j.dci.2009.04.002

Lugtenberg, B., and Kamilova, F. (2009). Plant-growth-promoting rhizobacteria. Annu. Rev. Microbiol. 63, 541-556. doi: 10.1146/annurev.micro. 62.081307 .162918

Lundberg, D. S., Lebeis, S. L., Paredes, S. H., Yourstone, S., Gehring, J., Malfatti, S., et al. (2012). Defining the core Arabidopsis thaliana microbiome. Nature 488, 86-94. doi: $10.1038 /$ nature11237

Lynch, M. D. J., and Neufeld, J. D. (2015). Ecology and exploration of the rare biosphere. Nat. Rev. Microbiol. 13, 217-229. doi: 10.1038/nrmicro3400

Madigan, M. T., and Gest, H. (1979). Growth of the photosynthetic bacterium Rhodopseudomonas capsulata chemoautotrophically in darkness with $\mathrm{H}_{2}$ as the energy source. J. Bacteriol. 137, 524-530. doi: 10.1007/BF00402298

Martens, R. (1990). Contribution of rhizodeposits to the maintenance and growth of soil microbial biomass. Soil Biol. Biochem. 22, 141-147. doi: 10.1016/00380717(90)90078-E

Mehnaz, S., Weselowski, B., and Lazarovits, G. (2007). Azospirillum zeae sp. nov., a diazotrophic bacterium isolated from rhizosphere soil of Zea mays. Int. J. Syst. Evol. Microbiol. 57, 2805-2809. doi: 10.1099/ijs.0.65128-0

Mejia, A. Y., Rotini, A., Lacasella, F., Bookman, R., Thaller, M. C., Shem-Tov, R., et al. (2016). Assessing the ecological status of seagrasses using morphology, biochemical descriptors and microbial community analyses. A study in Halophila stipulaceae (Forsk.) Aschers meadows in the northern Red Sea. Ecol. Indic. 60, 1150-1163. doi: 10.1016/j.ecolind.2015.09.014

Mendes, R., Garbeva, P., and Raaijmakers, J. M. (2013). The rhizosphere microbiome: significance of plant beneficial, plant pathogenic, and human pathogenic microorganisms. FEMS Microbiol. Rev. 37, 634-663. doi: 10.1111/1574-6976.12028

Mendes, R., Kruijt, M., de Bruijn, I., Dekkers, E., Van der Voort, M., Schneider, J. H. M., et al. (2011). Deciphering the rhizosphere microbiome for diseasesuppressive bacteria. Science 332, 1097-1100. doi: 10.1126/science.1203980

Meyer, B., and Kuever, J. (2007). Molecular analysis of the diversity of sulfatereducing and sulfur-oxidizing prokaryotes in the environment, using aprA as functional marker gene. Appl. Environ. Microbiol. 73, 7664-7679. doi: 10.1128/AEM.01272-07

Miller, S. H., Elliot, R. M., Sullivan, J. T., and Ronson, C. W. (2007). Host-specific regulation of symbiotic nitrogen fixation in Rhizobium leguminosarum biovar trifolii. Microbiology 153, 3184-3195. doi: 10.1099/mic.0.2007/006924-0

Miralles, G., Grossi, V., Acquaviva, M., Duran, R., Claude Bertrand, J., and Cuny, P. (2007). Alkane biodegradation and dynamics of phylogenetic subgroups of sulfate-reducing bacteria in an anoxic coastal marine sediment artificially contaminated with oil. Chemosphere 68, 1327-1334. doi: 10.1016/j.chemosphere.2007.01.033

Muyzer, G., and Stams, A. J. M. (2008). The ecology and biotechnology of sulphatereducing bacteria. Nat. Rev. Microbiol. 6, 441-454. doi: 10.1038/nrmicro1892

Newton, A., and Mudge, S. M. (2003). Temperature and salinity regimes in a shallow, mesotidal lagoon, the Ria Formosa, Portugal. Estuar. Coast. Shelf Sci. 53, 73-85. doi: 10.1016/S0272-7714(02)00332-3

Ofek-Lalzar, M., Sela, N., Goldman-Voronov, M., Green, S. J., Hadar, Y., and Minz, D. (2014). Niche and host-associated functional signatures of the root surface microbiome. Nat. Commun. 5, 4950. doi: 10.1038/ncomms5950

Ouisse, V., Migné, A., and Davoult, D. (2010). Seasonal variations of community production, respiration and biomass of different primary producers in an intertidal Zostera noltii bed (Western English Channel, France). Hydrobiologia 649, 3-11. doi: 10.1007/s10750-010-0254-3

Ouisse, V., Riera, P., Migné, A., Leroux, C., and Davoult, D. (2012). Food web analysis in intertidal Zostera marina and Zostera noltii communities in winter and summer. Mar. Biol. 159, 165-175. doi: 10.1007/s00227-011-1796-2

Papenbrock, J. (2012). Highlights in seagrasses' phylogeny, physiology, and metabolism: what makes them special? ISRN Bot. 2012, 103892. doi: $10.5402 / 2012 / 103892$

Parks, D. H., Tyson, G. W., Hugenholtz, P., and Beiko, R. G. (2014). STAMP: statistical analysis of taxonomic and functional profiles. Bioinformatics 30, 3123-3124. doi: 10.1093/bioinformatics/btu494 
Philippot, L., Raaijmakers, J. M., Lemanceau, P., and Van der Putten, W. H. (2013). Going back to the roots: the microbial ecology of the rhizosphere. Nat. Rev. Microbiol. 11, 789-799. doi: 10.1038/nrmicro3109

Platen, H., Temmes, A., and Schink, B. (1990). Anaerobic degradation of acetone by Desulfococcus biacutus spec. nov. Arch. Microbiol. 154, 355-361. doi: 10.1007/BF00276531

Prosser, J. L. (2010). Replicate or lie. Environ. Microbiol. 12, 1806-1810. doi: 10.1111/j.1462-2920.2010.02201.x

Ravikumar, S., Gnanadesigan, M., Saravanan, A., Monisha, N., Brindha, V., and Muthumari, S. (2012). Antagonistic properties of seagrass associated Streptomyces sp. RAUACT-1: a source for anthraquinone rich compound. Asian Pac. J. Trop. Med. 5, 887-890. doi: 10.1016/S19957645(12)60165-5

Rosenberg, E., Koren, O., Reshef, L., Efrony, R., and Zilber-Rosenberg, I. (2007). The role of microorganisms in coral health, disease and evolution. Nat. Rev. Microbiol. 5, 355-362. doi: 10.1038/nrmicro1635

Saxe, H. (1996). "Physiological and biochemical tools in diagnosis of forest decline and air pollution injury to plants," in Plant Response to Air Pollution, eds M. Yunus and M. Iqbal (New York, NY: John Wiley \& Sons), 449-487.

Shaw, G. E. (1983). Bio-controlled thermostasis involving the sulfur cycle. Clim. Change 5, 297-303. doi: 10.1007/BF02423524

Shieh, W. Y., and Yang, J. T. (1997). Denitrification in the rhizosphere of the two seagrasses Thalassia hemprichii (Ehrenb.) Aschers and Halodule uninervis (Forsk.) Aschers. J. Exp. Mar. Biol. Ecol. 218, 229-241. doi: 10.1016/S00220981(97)00076-2

Smith, A. C., Kostka, J. E., Devereux, R., and Yates, D. F. (2004). Seasonal composition and activity of sulfate-reducing prokaryotic communities in seagrass bed sediments. Aquat. Microb. Ecol. 37, 183-195. doi: 10.3354/ame037183

Smith, R. D., Pregnall, A. M., and Alberte, R. S. (1988). Effects of anaerobiosis on root metabolism of Zostera marina (eelgrass): implications for survival in reducing sediments. Mar. Biol. 98, 131-141. doi: 10.1007/BF00392668

Spaink, H. P. (2000). Root nodulation and infection factors produced by rhizobial bacteria. Annu. Rev. Microbiol. 54, 257-288. doi: 10.1146/annurev.micro.54.1.257

Sutherland, R. A. (1998). Loss-on-ignition estimates of organic matter and relationships to organic carbon in fluvial bed sediments. Hydrobiologia 389, 153-167. doi: 10.1023/A:1003570219018

Tanner, M. A., Everett, C. L., Coleman, W. J., Yang, M. M., and Youvan, D. C. (2000). Complex microbial communities inhabiting sulfide-rich black mud from marine coastal environments. Biotechnol. Alia 8, 1-16.

Thomas, F., Giblin, A. E., Cardon, Z. G., and Sievert, S. M. (2014). Rhizosphere heterogeneity shapes abundance and activity of sulfur-oxidizing bacteria in vegetated salt marsh sediments. Front. Microbiol. 5:309. doi: 10.3389/fmicb. 2014.00309

Ting, A. S. Y., Tan, S. H., and Wai, M. K. (2009). Isolation and characterization of actinobacteria with antibacterial activity from soil and rhizosphere soil. Aust. J. Basic Appl. Sci. 3, 4053-4059.

Tkacz, A., Cheema, J., Chandra, G., Grant, A., and Poole, P. S. (2015). Stability and succession of the rhizosphere microbiota depends upon plant type and soil composition. ISME J. 9, 2349-2359. doi: 10.1038/ismej. 2015.41

van der Heide, T., Govers, L. L., De Fouw, J., Olff, H., Van der Geest, M., Van Katwijk, M. M., et al. (2012). A three-stage symbiosis forms the foundation of seagrass ecosystems. Science 336, 1432-1434. doi: 10.1126/science. 1219973

van der Maarel, M. J. E. C., Van Bergeijk, S., Van Werkhoven, A. F., Laverman, A. M., Meijer, W. G., Stam, W. T., et al. (1996). Cleavage of dimethylsulfoniopropionate and reduction of acrylate by Desulfovibrio acrylicus sp. nov. Arch. Microbiol. 166, 109-115. doi: 10.1007/s002030050363

Wagner, C., and Stadtman, E. R. (1962). Bacterial fermentation of dimethyl$\beta$-propiothetin. Arch. Biochem. Biophys. 98, 331-336. doi: 10.1016/00039861(62)90191-1

Ward, N. L., Challacombe, J. F., Janssen, P. H., Henrissat, B., Coutinho, P. M., $\mathrm{Wu}, \mathrm{M}$., et al. (2009). Three genomes from the phylum Acidobacteria provide insight into the lifestyles of these microorganisms in soils. Appl. Environ. Microbiol. 75, 2046-2056. doi: 10.1128/AEM.02294-08

Wentworth, C. K. (1922). A scale of grade and class terms for clastic sediments. J. Geol. 30, 377-392. doi: 10.1086/622910

Wicks, E. C., Koch, E. W., O’Neil, J. M., and Elliston, K. (2009). Effects of sediment organic content and hydrodynamic conditions on the growth and distribution of Zostera marina. Mar. Ecol. Prog. Ser. 378, 71-80. doi: 10.3354/ meps07885

Widdel, F. (2006). “The genus Desulfotomaculum," in The Prokaryotes (Bacteria: Firmicutes, Cyanobacteria), Vol. 4, eds M. Dworkin, S. Falkow, E. Rosenberg, K.-L. Schleifer, and E. Stackebrandt (New York, NY: Springer), 787-794.

Wu, H., Chen, W., Wang, G., Dai, S., Zhou, D., Zhao, H., et al. (2012). Culturedependent diversity of Actinobacteria associated with seagrass (Thalassia hemprichii). Afr. J. Microbiol. Res. 62, 87-94. doi: 10.5897/AJMR11.981

Yoch, D. C. (2002). Dimethylsulfoniopropionate: its sources, role in the marine food web, and biological degradation to dimethylsulfide. Appl. Environ. Microbiol. 68, 5804-5815. doi: 10.1128/AEM.68.12.5804-5815.2002

Zeng, Y., Zou, Y., Chen, B., Grebmeier, J. M., Li, H., Yu, Y., et al. (2010). Phylogenetic diversity of sediment bacteria in the northern Bering Sea. Polar Biol. 34, 907-919. doi: 10.1007/s00300-010-0947-0

Zilber-Rosenberg, I., and Rosenberg, E. (2008). Role of microorganisms in the evolution of animals and plants: the hologenome theory of evolution. FEMS Microbiol. Rev. 32, 723-735. doi: 10.1111/j.1574-6976.2008.00123.x

Conflict of Interest Statement: The authors declare that the research was conducted in the absence of any commercial or financial relationships that could be construed as a potential conflict of interest.

Copyright (C) 2016 Cúcio, Engelen, Costa and Muyzer. This is an open-access article distributed under the terms of the Creative Commons Attribution License (CC BY). The use, distribution or reproduction in other forums is permitted, provided the original author(s) or licensor are credited and that the original publication in this journal is cited, in accordance with accepted academic practice. No use, distribution or reproduction is permitted which does not comply with these terms. 